\title{
LA ASOCIACIÓN ILÍCITA COMO MÉTODO DE CLONACIÓN DE PROCESOS
}

\section{THE ILLICIT ASSOCIATION AS A PROCESS CLONING METHOD}

Eugenio Raúl Zaffaroni Juez de la Corte Interamericana de Derechos Humanos. Profesor emérito de Derecho Penal

Universidad de Buenos Aires

Argentina. Buenos Aires

Guido Leonardo Croxatto Investigador CONICET

Universidad de Buenos Aires Argentina. Buenos Aires

\section{SUMARIO}

- Un poco de historia.

- El Derecho dúctil

- La asociación ilícita, un tipo penal de constitucionalidad dudosa

- La prisión preventiva: de excepción a norma ilegítima

- Conclusiones

- Fuentes de información.

\section{RESUMEN}

En este trabajo abordamos críticamente la figura de la asociación ilícita bajo una doble perspectiva: histórica y constitucional, cuestionando sus basamentos teóricos y su utilización jurisprudencial. Conectamos su empleo con procesos penales arbitrarios donde las garantías procesales suelen ser vulneradas. Recuperamos su historia política en tiempos de la caza de brujas, cuando nace el término "asociación subversiva", en tiempos de persecución del aquelarre, tomado por muchos historiadores contemporáneos (sobretodo feminista como Silvia Federici) como formas de resistencia a nuevas formas de organización de la propiedad rural (ya que detrás de la caza de brujas estuvo la expansión del capitalismo rural) o de resistencia a la privatización de las tierras en Europa.

Concluimos, haciendo un paralelo con la caza de brujas (programa político de criminalización), que la alternativa a la criminalización constante y creciente de sectores marginados (réplica histórica de aquel proceso político, acompañado por la Inquisición, de cuyas prácticas no parecen haberse librado del todo nuestros tribunales: el modelo inquisitivo sigue vigente $^{1}$ ) debe pasar por la construcción crítica de un derecho latinoamericano consciente de sus desafíos sociales y sobretodo económicos, conflictos que siempre se traducen en prácticas punitivas. Proponemos, en definitiva, la construcción (frente al auge presuntamente neutral y apolítico de la gobernanza carcelaria) de un Derecho -y una criminología y un Estadoque deje(n) de buscar brujas para cazar ${ }^{2}$. Pauta

1 Posición que ha sido compartida por el profesor Gino Ríos, Director del Instituto de Investigación Jurídica de la Universidad de San Martín de Porres (USMP) y el colega limeño Renzo Espinoza, cuyos valiosos consejos agradecen los autores.

2 Puede decirse que las dos grandes brujas artifices de la gran corrupción política de la región han sido, sin dudas, previo a la restauración de gobiernos neoconservadores que hacen apología de la tecnocracia neoliberal, neutral y apolitica, las corruptas y brujas Cristina Kirchner y Dilma Rousseff. (Si uno toma el análisis de Silvia Federici, que rescata la capacidad de curar de las "brujas", que los gobiernos populistas penales revindiquen, además -y vuelvan laxo- el uso de armas, debiera motivarnos reflexiones histórico comparativas elocuentes, tomando al feminismo como una reacción social interesante en varios niveles). Dos brujas (yeguas) condenadas y perseguidas mediática y judicialmente en procesos cuyas arbitrariedades e irregularidades (anti garantistas), como en el caso de Lula, están a la vista o han quedado por demás en evidencia. Lula, Cristina, Dilma, Correa, hayan hecho lo que hayan hecho, encarnan la peor corrupción (de la) política. La mancha de la corrupción simbólica como resistencia al avance de la gobernanza neoliberal (el viejo avance supuesto de la libertad). Como gobierno. Por eso ya no se habla más de gobierno: se habla de gobernanza. Sólo el primero es politico (es política, es corrupto, es populista, genera conflictos), el segundo se asume como técnico, como ideologia neutral. La misma tecnocracia liberal chilena que propugna como modelo eficiente y modernizador el Chile de Pinochet. Una dictadura sangrienta, alabada y propuesta como ejemplo a seguir 
que puede servir también, a más de tres décadas de que Rosa del Olmo y Lola Anillar de Castro (no casualmente dos mujeres, dos "brujas") introdujeran la criminología critica en toda América Latina, para repensar los nuevos desafíos que enfrenta nuestra criminología en la actualidad.

\section{ABSTRACT}

In this work we critically approach the figure of the illicit association from a double perspective: historical and constitutional, questioning its theoretical foundations and its jurisprudential use. We connect your employment with arbitrary criminal proceedings where procedural guarantees are usually violated. We recover its political history in times of witch hunts, when the term "subversive association is born, in times of persecution of the coven, taken by many contemporary historians (especially feminist as Silvia Federici) as forms of resistance to new forms of organization of

por neo liberales. (Friedman) En esos casos, naturalmente, no se habla de las dictaduras que recortan derechos civiles como de una asociación ilícita. Son regimenes que modernizaron un país. Que sanearon una economía. En esos casos se cambia rápidamente el registro, se altera el discurso. Lo que debe investigarse es cómo los tribunales representan la criminalidad (la violencia, la corrupción) en un caso y en otro: qué conceptos han empleado para pensar y nombrar el crimen. Y sobretodo para no nombrarlo. Qué se representa como corrupción y qué no se etiqueta con esa palabra, siendo sin embargo mucho más grave para el desarrollo de nuestros países. El crimen del subdesarrollo (a que millares son expulsados a diario como resultado técnico de políticas macroeconómicas apoliticas y neutrales, puras) todavia no ha encontrado un nombre, carece de tipo penal. La concentración de recursos (la fuga de recursos) es una de sus caras más elocuentes. Esto también expresa una corrupción, pero es una corrupción que no se nombra. Que no tiene nombre. (No todo se presenta como corrupto, lo otro de lo corrupto es lo técnico) Los que la llevan adelante no son corruptos. Ellos no. (Silvia Federici explica que "La acusación de brujería cumplió una función similar a la que cumple la acusación de traición (...) -y la acusación de terrorismo- en nuestra época". Muchos procesos penales actuales acusan de presunta asociación ilícita y presunto delito de traición -a la patria- al mismo tiempo a muchos gobiernos de brujas actuales de la vida política, como la ex presidenta argentina y su hija, actualmente bajo tratamiento médico en Cuba. Federici, Silvia, "La gran caza de brujas en Europa", en: Calibán y la bruja. Mujeres, cuerpo y acumulación originaria, trad. Verónica Hendel y Leopoldo Sebastián Touza, Buenos Aires, Tinta limón, 2a reimpresión, 2018, pág. 233. Como recuerda Federici, el objetivo último de estas prácticas de criminalización de la brujería -y para eso sirvió la figura de la asociación subversiva, antecedente directo de la asociación ilicita- era erradicar y castigar cualquier tipo de protesta: hoy este tipo penal sirve para criminalizar dirigentes como Berta Cáceres en Honduras o Milagro Sala en Jujuy, Argentina, y agrupaciones politicas, estudiantiles o sindicales: la lógica es -sigue siendo- la caza de brujas, siendo brujas las que hacen oposición, como Marielle Franco, rescatando los derechos civiles y humanos de la población marginada y vulnerable, que en rigor es una población vulnerada, no "vulnerable", porque la vulneración es un hecho, no una potencialidad posible y abstracta, sino una realidad cruda) rural property (since behind the witch hunt was the expansion of rural capitalism) or resistance to the privatization of land in Europe.

We conclude, making a parallel with the witch hunt (political criminalization program), that the alternative to the constant and growing criminalization of marginalized sectors (historical replica of that political process, accompanied by the Inquisition, whose practices do not seem to have escaped the all our courts: the inquisitive model is still in force) must go through the critical construction of a Latin American law aware of its social and economic challenges, conflicts that always translate into punitive practices. We propose, in short, the construction (in the face of the allegedly neutral and apolitical boom of prison governance) of a Right - and a criminology and a State - to stop looking for witches to hunt. A guideline that can also serve more than three decades of Rosa del Olmo and Lola Anillar de Castro (not coincidentally two women, two "witches") introducing critical criminology throughout Latin America, to rethink the new challenges facing our criminology nowadays.

\section{PALABRAS CLAVE}

Asociación ilítica; clonación de procesos; derecho dúctil.

\section{KEYWORDS}

Illicit association; process cloning; ductile right.

\section{UN POCO DE HISTORIA}

Jean Bodin, célebre abogado y teórico político francés, autor del primer tratado sobre la inflación que se conozca, participó en muchos juicios sobre brujas y escribió un libro sobre pruebas, (Demomanía, 1580) en el que insistía en que las brujas debían ser quemadas vivas, en lugar de ser misericordiosamente estranguladas antes de ser arrojadas en las llamaradas; que debían ser cauterizadas, así su carne se pudría antes de morir; y que sus hijos también debían ser quemados. Bodin no fue un caso aislado ${ }^{3}$.

3 Puede pensarse que la demonologia es un antecedente directo de nuestros criminólogos. La demonología medieval es un buen espejo en el que la criminologia puede (volver a) mirarse. 
Ya en la antigua Grecia se entendía que los hijos portaban la culpa de los padres de manera casi automática. No hacía falta probar nada: bastaba con ser hijo de, para ser corresponsable de cualquier delito o imputación. Esta lógica antigua, arcaica, fue lentamente abandonada hasta llegar al derecho penal moderno, producto del liberalismo ilustrado, que pone en el centro la responsabilidad personal por cada conducta: el derecho penal de acto. Nadie hereda ya culpa alguna. Cada uno es responsable de lo que hace. Por un hacer. No por un ser. Nadie es acusado por ser alguien, sino por hacer algo. Aunque Florencia Kirchner es acusada en Argentina por ser la hija de. Como una forma de extorsión y amenaza, reforzada en tiempos electorales. Hija de.

Pero el retroceso en materia de derechos humanos que se vive en todo el continente (sobretodo Argentina y Brasil) y gran parte del mundo, que está detrás de los procesos con intereses políticos (Lula, Correa, Lugo, Cristina, pero también el proceso a Assange, Scott Waren, Snowden, Carol Rackete, y todo otro activista civil y de derechos), ha generado una vuelta del llamado derecho penal del enemigo, al que se recortan todas las garantías civiles, penales, procesales. El enemigo no tiene derechos. Por eso este discurso va de la mano de una crítica constante de todo garantismo. Porque las garantías operarían como un límite para la persecución arbitraria, un límite también en la guerra al delito, que nunca es el crimen sofisticado que cometen a diario las grandes empresas y sus delegados políticos. El crimen penado es el crimen de los pobres.

El retroceso anti liberal (del cual la falta de derechos sociales y económicos es parte, no casualmente se procesan líderes que rescatan esos derechos) que vivimos, con procesos ilegales, prisiones sin condena, presos preventivos por peligrosidad, tipo que no existe en nuestro ordenamiento, presidentes que públicamente celebran la violencia policial (Bolsonaro), los crímenes del Estado (la masacre den San Miguel del Monte, el asesinato de Maldonado o Nahuel en el sur argentino) obedecen a este proceso político de erosión constante de las garantías. De crítica del garantismo que expresa nuestra ley fundamental: ya que -más allá de las críticas mediáticas- nuestra constitución es garantista. Nuestra constitución defiende las garantías.
No es casual que la persecución se extienda, como en cualquier estado que deja de ser de Derecho, a amigos, familiares, conocidos, ex funcionarios (todos como miembros de una gran asociación ilícita, un tipo que nace para acorralar, perseguir y estigmatizar a la oposición y a la protesta). De este modo, Florencia Kirchner es doblemente culpable: se la acusa de conformar dos veces una asociación ilícita: la de un gobierno (cuyos ex funcionarios habrían conformado todos una asociación para delinquir) y la de su propia familia, ya que en un gesto extravagante y penoso el juez Bonadio interpreta que el mismo día que Florencia perdió a su papá, pasó a conformar de hecho y derecho una asociación ilícita como heredera. Todo esto por ser. No por hacer nada. Solo que el fondo de esta interpretación peligrosista (y jakobsiana, hoy tan de moda en la región) (Zaffaroni, 2016) está prohibida por ley (en Argentina). Es ilegal.

Muchas personas procesadas y perseguidas por corrupción son mujeres. Porque nuestro poder judicial, conformado casi en su totalidad por hombres, no se le anima con la misma facilidad, con la misma valentía, a las corruptas que a los corruptos. Muchos procesos sobre corrupción pública, que han exonerado a casi todos los grandes empresarios de nuestro país (Argentina), tienen un doble condimento anti político: primero, que la política es en última instancia la única que queda, en consonancia con el discurso del marketing del gobierno (donde el mercado es limpio y puro), manchada como corrupta, como sucia (como mujer). En segundo lugar, que corruptas son, como en la época en que se combatía el aquelarre campesino (so pretexto de cazar brujas, que no eran sino mujeres que se resistían a las arbitrariedades del poder de su tiempo) sólo las mujeres. Cristina es, en todo sentido, como mujer, como política, como Sala y Florencia, los grandes símbolos de la corrupción kirchnerista. De la politización de la ideología de las mujeres. Por eso se las persigue con ahínco en procesos arbitrarios donde no se respeta ninguna garantía procesal. Ningún garantismo. Son mujeres (como Dilma) que han hecho política y eso no se perdona; menos haber cuestionado al poder económico y mediático. No pueden no ser, para la justicia del patriarcado, tan afín y susceptible a la presión de los grandes medios, brujas, yeguas y corruptas. Enemigas sin derechos. Ya en la edad media la acusación de brujería iba 
de la mano de la acusación de asociación subversiva. Las mujeres que se organizaban para resistir el avance del capitalismo rural y la privatización de sus tierras, sobretodo en Europa, eran acusadas de brujas. La caza de brujas fue, como recuerda Silvia Federici, parte de un proceso no solo legal o religioso, sino sobre todo el corolario de un proceso económico, al que jueces, abogados, teólogos, demonólogos, filósofos (de la talla de Hobbes) dieron sobrados argumentos.

También en la Edad Media, como advertíamos, la acusación de brujería iba por lo general de la mano de la acusación de asociación subversiva (Federici, 2018, pág. 235). No eran acusaciones aisladas, sino parte de un mismo programa político de criminalización y control social.

El concepto de corrupción, como advierte el historiador norteamericano Eugene Weber, tiene una historia que merece y necesita ser contada. Norberto Bobbio ha sostenido no sin razón que la crítica anti corrupta presupone una noción de pureza social (no republicana), de política limpia, que fue propia de los fascismos europeos, con su racismo genocida que buscaba extirpar todo síntoma de corrupción parasitaria del cuerpo social puro y a preservar de los corruptos, de los que traían consigo una corrupción (binding). Este lenguaje puede ser estigmatizante, como el de las brujas (de hecho la caza de brujas se ha convertido en un concepto por algo, ya no se refiere solo a un proceso histórico preciso, muy grave, sino también a un concepto punitivo, inquisidor y político, que traduce prácticas en cualquier época cuando se habla de caza de brujas, por ejemplo con el macartismo, se habla de otra cosa: es un concepto político, algo semejante a lo que acomete Adorno con Auschwitz, lo convierte en un concepto de lo penal, de la lógica punitiva de la sociedad industrializada y fría, la subjetivación burguesa (Adorno 1992) $)^{4}$. Weber dice algo semejante respecto de la aristocracia francesa en él, la caza de corruptos como la caza de brujas, tiene una larga historia detrás, que no siempre el derecho asume con la cautela crítica que debería, para no terminar en la criminalización peligrosista, anti liberal, que

\footnotetext{
4 Bauman (1998) no habla de modernidad u Holocausto, sino de modernidad y Holocausto. El holocausto no como algo externo o ajeno a la modernidad, alejado, sino como una parte intrínseca -inocultable y en el campo punitivo penal esta denuncia es evidente, con cárceles que funcionan como campos de exterminio penales- de ella misma. Teorizamos parados sobre una barbarie. Sobre una pila de cuerpos.
}

hoy vemos expandirse nuevamente, haciendo de la ayuda humanitaria un delito, colmo de la inversión del garantismo. Se vuelve un crimen ayudar. Salvar vidas.

Eduardo De Lázzari, Presidente de la Corte Suprema de Justicia de la Provincia de Buenos Aires, acaba de reconocer que existen en la Argentina causas (judiciales) armadas artificialmente 5 , por puro interés mediáticopolítico, con la venia de un poder judicial casi enteramente corrupto. Que un presidente de una corte provincial sostenga que la justicia como poder se encuentra corroído por dentro, que ha perdido de vista sus principios esenciales, que es infiltrada por servicios de inteligencia, que extorsionan funcionarios, condicionando o direccionando su tarea, (como en cualquier estado no democrático, donde la prensa y la justicia son cooptadas y condicionadas en su labor independiente), no es un accidente: porque lo que este presidente de un tribunal expresa es que muchas de las causas sobre asociación ilícita armadas sobretodo en tiempos electorales en la Argentina, son causas armadas, causas truchas, donde muchos funcionarios o ex funcionarios son forzados por la propia justicia y en base a una ley de constitucionalidad muy dudosa (coaccionando a los imputados a auto involucrarse o involucrar a terceros -delatar- para obtener supuestos beneficios, lo cual es ilegal cuando es producto de una negociación con la Justicia, de un pacto o arreglo, ya que los beneficios se otorgan en función de criterios técnicos y objetivos, no de acuerdos espurios o negociados entre la justicia y los imputados), a arrepentirse y darle pábulo al armado de causas mediáticas. El Poder Judicial es el poder del Estado sobre el cual recae la mayor tasa de desconfianza de la ciudadanía argentina. Y esto tampoco parece un accidente. Al histórico déficit de origen (la objeción contra mayoritaria) puede sumarse en la última década un estridente déficit de independencia y un aumento en la estructural selectividad punitiva sobre los desclasados,

\footnotetext{
5 El presidente de la Corte Suprema bonaerense, Eduardo De Lázzari, denunció "el armado de causas judiciales", "los abusos de arrepentidos y testigos de identidad reservada" y "las condenas mediáticas", desarrollados por "espias y traficantes de escuchas con la complicidad de algunos magistrados". Este es el escenario ya habitual de un poder judicial muy poco independiente. No se equivoca De Lázzari cuando sostiene que el único instrumento con que cuentan los magistrados para revertir esta crisis judicial es el pripio Derecho "ejercido con firmeza, con valor". No otra cosa es la defensa firme de las garantias. La defensa firme del Derecho (Diario Página 12, 2019).
} 
estigmatizados como los únicos delincuentes. Esto genera un sistema que termina dando una justicia para los poderosos, y cárcel para los pobres como medida de control social, de neutralización. Por eso el estado de abandono de las cárceles: porque nadie espera que salgan (resocializados...) de allí. Se espera, como se repite en la cultura popular, que se "pudran en la cárcel". No que se resocialicen. El lenguaje popular desmiente cualquier teoría criminológica. Cualquier veleidad de la Academia Penal. El lenguaje popular resume muy bien las contradicciones republicanas ${ }^{6}$.

\section{EL DERECHO DÚCTIL}

Gustavo Zagrebelsky ha hablado no sin razón sobre la emergencia de un derecho "dúctil". Nosotros entendemos que nuestro Derecho constitucional está acostumbrándose demasiado a doblarse, a pervertirse, (es demasiado "ductil", para proseguir con la metáfora del profesor italiano, diríamos que tenemos hoy un Derecho Procesal, Penal e incluso Constitucional -e Internacional Humanitario- que es o se ha vuelto dúctil en exceso $^{7}$ ) perdiendo su perspectiva fundamental, que es la del básico respeto de las garantías procesales penales, (y humanas, constitucionales, en tantos planos y ramas) hoy amenazadas (Zagrebelsky, 2016). Por eso compartimos con el maestro Luigi Ferrajoli,

6 Desde la antigüedad -del teatro griego- heredamos un concepto que debe ser estudiado en profundidad, porque en él se esconde la raiz de mucho de lo que hacemos los penalistas aun hoy: el pathei mathos. La idea de que se puede aprender a través del sufrimiento. A través de la imposición de un castigo. De un mal. De que con la tortura se "aprende", como en el cuento de Kafka, la colonia penitenciaria, de que con la Rastra que escribe la letra (la letra con sangre entra) del Derecho en el cuerpo entumecido del condenado, se "aprende", el torturado llega a ver, mientras se inscribe el Derecho en su cuerpo, el "mensaje", la "verdad", de mano de la tortura, de la pena. Cuando el lenguaje popular justifica la violencia policial, los linchamientos, la tortura en las cárceles, con frases del tipo "está bien, tienen que aprender... alguien les tiene que "enseñar", estan replicando esta vieja, primitiva idea, ya presente en el teatro griego de Esquilo: el pathei mathos, como nucleo de nuestro sistema penal. Tan poco hemos "evolucionado", seguimos parados no ya en la edad Media, como suele repetir Zaffaroni, sino mucho antes incluso: en la Antiguedad. Tan poco nos hemos "modernizado". La modernidad es una asignatura pendiente. El camino para el liberalismo, como repetía Zaffaroni en Frankfurt con Naucke almorzando juntos en 2014 en el Sturm und Drang, es uno solo: es la no legitimación del castigo. La no legitimación de la pena. La deslegitimación de este mal que tortura y agrava conflictos sociales. Nunca los "soluciona" (Kafka, 1999).

7 En otros trabajos hemos insistido ya sobre los riesgos de una excesiva "ductilidad" en el Derecho positivo (no muy distinta de la crítica de Jürgen Habermas al principalismo no positivista de Robert Alexy, al que Habermas acusa de quebrar una "barrera" de fuego: la legalidad). Véase Alen, L. y Croxatto, G. L. (2018). también profesor en Italia, discípulo del maestro Bobbio, quien prologa su obra decisiva ${ }^{8}$, la idea de que el método propio del constitucionalismo garantista (que defendemos), es el positivismo jurídico estricto, a diferencia de otros neo constitucionalismos muy de moda en la región y su jurisprudencia, como el constitucionalismo principista (del profesor alemán Robert Alexy, no por accidente cuestionado por Klaus Gunter y su maestro en Frankfurt, el profesor Jurgen Habermas (1998)), que rescata y reconoce abiertamente ser no positivista. Habermas entiende que el no positivismo de Alexy, de moda en nuestros países, cruza una delgada pero trascendental "línea de fuego", la que otorga al Derecho su caracter perentorio, su nota normativa. Entendemos que el "no positivismo" de moda puede entrañar un severo riesgo para la práctica judicial latinoamericana, crecientemente conservadora en materia de operativización de derechos sociales y económicos, pero (o en forma coherente) crecientemente activista a la hora de encarcelar opositores (en su mayoría, líderes populares, defensores, precisamente, de aquellos derechos sociales y económicos de las mayorías desclasadas, derechos que muchas veces se dejan de lado con eufemismos banales, como el eufemismo de la "no operatividad") . Detrás de muchos de estos procesos, pues, se expresa la misma lógica económica realista (en nombre de la "eficiencia" del mercado) que expresan muchos gobiernos neoconservadores. Esta simbiosis termina por expresar, en definitiva, la falta de independencia e imparcialidad (desapego constitucional positivista, desapego a las garantías escritas, estrictas, jurídicas, normativizadas, positivizadas en procesos constitucionales legales) de muchos de nuestros tribunales de justicia: una misma politica macroeconómica acompañada de un continuo recorte (realista) de derechos, que se convierte así en política de Estado (Zaffaroni, 2019). Este discurso tiene la curiosidad de ser compartido gobiernos neoliberales $y$ por grupos empresarios, que lo repiten sin fisuras. Expresa el auge de la denominada

8 Norberto Bobbio inauguró en la Argentina, en Buenos Aires, la carrera de Ciencias Políticas en la UBA con el retorno de la democracia, en 1983. Durante la dictadura militar no era pensable siquiera una carrera semejante, que pretendiese elevar los estudios sobre la vida política -prohibida y perseguida- al grado de ciencia.

9 No se observa el mismo activismo judicial a la hora de investigar los continuos crimenes a defensores de derechos humanos y del medio ambiente, como Marielle Franco, Berta Cáceres o Lesbia Yaneth, por mencionar solo algunos. Véase para entender estas tensiones: Ferrarjoli, L. (2011). 
“gobernanza", un nuevo lenguaje político. La crítica al garantismo penal y constitucional no supone pues solo un recorte (politizado y poco independiente, aunque se presenta al revés, como "republicano") de garantías y derechos durante el proceso penal, para los imputados previamente presentados como enemigos sin derechos ${ }^{10}$ (inversión de la carga de la prueba, penas sin condena ni proceso justo, presunción de culpabilidad, peligrosismo, derecho penal de autor, al ser peligroso) sino también en un amplio espectro de garantías sociales y derechos (laborales, sociales) recortados, también en nombre de un ataque al garantismo, presentado éste como ideología extrema, social, constitucional, y no solo penal ${ }^{11}$.

El auge del no positivismo, propio del principalismo, es un estrategia útil sin embargo (para el "realismo" económico y jurídico de los mercados y sus defensores neoliberales ${ }^{12}$ ), que hace perder de vista la preminencia positivista $\mathrm{y}$ positivista del derecho como norma (Habermas), dando paso, una vez abierta la compuerta (traspasada la línea de fuego, en términos de Habermas en su objeción central al principalismo de Alexy), al festival de interpretaciones, concretamente: al auge de los "argumentos". Existe una crisis del llamado estado legislativo de derecho, y existe una crisis del positivismo jurídico como escuela, porque existe una crisis de su principal instrumento: la legislación. Las normas jurídicas. La ley. Hoy las normas pasan a segundo plano. Su lugar lo ocupan, en momentos de fuerte descodificación normativa (debida también a la superposición demagógica y especulativa de leyes penales,

10 Feindstrafrecht es una categorización que no es nueva para los penalistas latinoamericanos, aunque hoy vive un momento de auge (también fue empleado este concepto para justificar zonas grises como Guantánamo, donde el derecho procesal e internacional no penetran), este auge del peligrosismo penal anti liberal (derecho penal de autor) es paralelo a la tendencia inconstitucional no positivista, crítica del garantismo y de los jueces garantistas, únicos que hacen bien su trabajo (pese a ser denostados en los medios, paradójicamente por): respetar y resguardar la constitución. Por resguardar el derecho positivo, escrito, estricto. La legalidad normativa liberal, base del estado de derecho moderno.

11 El garantismo es parte de una teoría -filosofia- igualitaria del Estado, que trasciende (aunque contempla) una mirada crítica sobre el área penal, donde muchas de las desigualdades previas terminan por reafirmarse. El sistema punitivo es parte de -y funciona como engranaje de- una estructura social y ecoomica muy precisa, muy "realista". Con intereses reales. Ferrajoli (2018). Véase el prólogo de Norberto Bobbio a la obra fundamental de Ferrajoli, uno de los cultores centrales del garantismo como teoria constitucional.

12 Ambos realismos (el economico y el juridico) van de la mano. Véase Croxatto (2018). que pervierten toda idea de "sistema" jurídico consistente coherente y codificado), los "argumentos". En vez de aplicar normas, los jueces se dedican hoy a desarrollar y a construir creativamente argumentos ${ }^{13}$. Si hoy

13 También en este punto deben tomarse en cuenta el nada casual auge de los estudios literarios (de ficciones y literatura) por parte de los abogados. Esto tiene a la vez caras positivisas, y riesgos no atendidos. Nussbaum (2012). Pero sobretodo, sin embargo, debe advertirse el auge de cursos de posgrado sobre argumentación jurídica, cursos que antes eran de apoyo, hoy pasan a ocupar la centralidad de la formación de los abogados: cómo saber argumentar. (Ante el desplazamiento de la centralidad de la norma, que hoy ocupa el "argumento", la motivación del fallo, en una nueva lógica realista, no positivista, por eso se arguye con razón que pasamos del Estado legislativo de Derecho, donde la norma juridica tenia el predominio, a un Estado constitucional de Derecho, donde más que las normas la clave viene dada por la constitución como ley fundamental, que debe ser aplicada por los jueces. Por eso, ante la crisis de su principal instrumento, la legislación, es que el positivismo jurídico como escuela entra en crisis, pasando a ser el Congreso un escenario de menor importancia relativa frente al Poder Judicial, que aplica la que tiene la centralidad, la constitución con su nueva eficacia directa, horizontal, no programática. Esto ha sido lúcidamente advertido por Luis Pietro Sanchís, ante la crisis de la norma jurídica, del Estado legislativo de Derecho, del Congreso como espacio de la legislación y del positivismo jurídico como doctrina que hace de la ley su principal instrumento, surge una nueva escuela realista, no positivista, neoconstitucional, que hace eje en la labor de los jueces, que deben fallar en funcion de la constitucion, que no siempre provee por si misma de buenos argumentos, que deben reconstruir los propios jueces, tambien porque el "Derecho" que tienen en sus manos ya no les otorga respuestas, tambien por el desorden, caos normativo, producto de la des-codificación progresiva, de la que los jueces, vale la pena aclarar, no son responsables). Y no es casual precisamente que los cultores de esta nueva moda académica, con cursos de "argumentación" por todo el mundo (siempre hubo que argumentar, pero hoy el argumento ocupa un lugar diferente, tiene una centralidad por sobre la norma incluso, cristalizando el viejo temor del positivismo: que la "intetpretacion" ahogue a la norma, que la interpretacion ahoge o desplace al Derecho, cuando el positivismo pedia jueces ciegos y objetivos e imparciales como máquinas, lo que Bobbio llamó el positivismo idelógico, que solamente apliquen el Derecho, lo hacia por su temor a la discrecionalidad interpretativa, como puerta de arbitrariedades "bien argumetadas", temor seguido hoy por Habermas, critico del principalismo), sean precisamente los cultores del no positivismo: Alexy, Manuel Atienza, y los seguidores de la teoria principalista, cuestionada por Habermas, maestro de Gunter, un penalista. No es casual tampoco, justamente, que un penalista, conciente de los riesgos de la descodificacion normativa (no "garantista", no "positivista") sea critico del principalismo no positivismo de Alexy. Porque sobretodo en el campo penal se advierten mejor los peligros de desarmar preceptos legales, garantías procesales taxativas, positivas, escritas. No es casual en este sentido tampoco, que Alexy siga el pensamiento filosofico de Kant, quien fuera cuestionado por Feuerbach padre, cultor "positivista" de la legalidad (a la que eleva al rango de principio constitucional "positivo" moderno), siendo este seguido actualmente por Luigi Ferrajoli, cultor "positivista" del actual garantismo, critico del pensamiento de aquel (Alexy) kantiano. Son dos lineas paralelas. E1 punto de debate es el mismo: no ha cambiado. Es casi una repetición, que a menudo desconocemos, por nuestro desconocimiento de la historia del derecho penal moderno y sus debate doctrinarios. Cambian los actores, no la acción. Las críticas de Feberuach padre a Kant son pues, en este aspecto, reveladoras y más sustanciales que sus diferencias -por otro lado explicitas- con Hobbes. Véase el estudio previo de Eugenio Zaffaroni al libro Paul Anselm von Feuerbach, Feuerbach, P. A. (2010). 
está de moda en el mundo la argumentación jurídica, con cientos de cursos y posgrados, es porque la norma jurídica, el derecho positivo, la ley escrita como instrumento normativo básico, ha sido erosionada, ha ido perdiendo su peso y centralidad jurídica. Por eso los jueces no solo no aplican (sino que interpretan) el Derecho, (algo que el positivismo jurídico siempre quiso evitar, hasta extremos de pedir jueces "máquina", para evitar toda infiltración personal arbitraria frente al Derecho, en el otro extremo, como forma de garantizar además cierta previsibilidad y "seguridad jurídica", expresión hoy de moda, ante la creciente "inseguridad" que despierta el "realismo" de nuestros tribunales, el festival de "interpretaciones" no positivistas, literarias, argumentativas o bien argumentadas, pero que muchas veces reproducen lógicas mediáticas que debieran precisamente acotar o discutir en defensa de las garantías, en lugar de replicar sin critica lo que exigen las tribunas mediáticas, no siempre constitucionistas ni garantistas, sino que dirimen en los tribunales lo que previamente fueron linchamientos mediáticos, estigmatizaciones deshumanizantes de personas no vistas como tales, sino como enemigos, delincuentes sin derechos humanos ${ }^{14}$ ) sino que, ante la incapacidad alegada del derecho de brindar respuestas claras, pero teniendo la obligación de fallar, y motivar sus fallos: los jueces argumentan (Siempre han argumentado, solo que hoy el argumento ocupa el lugar que antes ocupaba la norma, este desplazamiento explica que tengamos una jurisprudencia "realista" $\mathrm{y}$ un poder judicial activista en materia de interpretaciones, que fuerza muchas veces los límites de sus funciones en una democracia con división de poderes ${ }^{15}$ ). Ahora no alcanza

14 Cuestionando por "garantistas" a quienes se atreven a defender la sola -y básica- idea de que todos en una democracia tenemos derechos humanos, incluyendo quienes cometen delitos. Una idea constitucional elemental, hoy cuestionada y atribuida a una "ideologia": el "garantismo". Este es el nivel de nuestro retroceso institucional. Por eso jaria falta, como sostiene Mariela Belski, de Amnistía Internacional Argentina, volver a repetir -y volver a enseñar, sobretodo- el ABC del Derecho. El ABC del derecho constitucional, procesal penal, internacional humanitario. El ABC del Derecho: son las garantías. Y éstas no reconocen culpables de inocentes, son para todos. Son universales. Como la prohibición de tortura.

15 Puede pensarse si no existe en las democracias contemporáneas una crisis de la vieja doctrina de pesos y contrapesos. Nosotros entendemos que los poderes de Estado ya no se controlan ni contrapesan debidamente entre sí: compiten entre ellos, como burocracias cerradas, cada una resguardando y expandiendo sus esferas y su predominio. Esto termina con un presidente que gobierna por decreto, saltando al Congreso, que queda desvalido con aplicar una norma, ahora también hace falta argumentar con precisión. Construir argumentos que ocupan la centralidad de la sentencia, por sobre la norma escrita estricta. Esto es correcto desde el punto de vista de la fundamentación. Pero riesgoso cuando se hace en nombre de un neo "no positivismo" jurídico, de un nuevo iusnaturalismo que, en nombre de alguna moral republicana, deja de lado la norma escrita, común a todos, con prescindencia de nuestras interpretaciones y visiones políticas o sociales, religiosas, morales. Este es o fue el quid de la modernidad jurídica. Y no es casual que este discurso principalista este en auge en tribunales en países donde a su vez se cuestiona al garantismo (lo cual no es, por otro lado,

como mera "escribanía" y un poder judicial activista, aunque no en materia de derechos economicos y sociales, es un activismo judicial conservador, que a menudo tiene connotaciones políticas precisas, lo que acredita poca independencia en sus funciones. De este modo el cuadro institucional es desalentador y poco o nada republicano, detrás de esta crisis republicana de la "division de poderes", lo que subsiste es una crisis de la ingeniera basica del sistema republicano moderno: la idea de pesos y contrapesos, de poderes que se contrapesan debidamente entre sí, en lugar de funcionar como burocracias independientes y aisladas, desdibujando cualquier atisbo de republicanismo. Esto afecta la calidad democrática y deliberativa. Por eso hemos propuesto, en línea con Max Weber en Alemania, el avance hacia un sitema político parlamentario. Weber entiende que Bismark habia dejado a la sociedad alemana con un vacio cuando deja el poder (que habia ejercido como caudillo), falta de competencias politicas y de hábitos de deliberación de ideas. Algo semejante puede decirse de nuestros hiperpresidencialismos latinoamericanos, que gobiernan cualquier campo por decreto de necesidad y urgencia (la excepcionalidad devenida norma, vivemos en la excepcionalidad permanente, en estado de excepción, lo cual justifica el recorte de derechos y el recorte de funciones institucionales, el recorte de garantias y la critica pueril aunque riesgosa al garantismo como nuevo lugar común, el anti garantismo entrana una forma de discurso de odio, de estigmatizacion y denegación de derechos al "enemigo" interno, social, no visto como humano, por eso se lo lincha en la vereda, se lo ata un arbol o quema, se justifica la violencia policial, la tortura, y se denuesta a los jueces que preservan las garantias basicas, por "garantistas" aliados de los "delincuentes", que no debieran tener derechos humanos en esta lectura peligrosista y anti liberal, tan de moda y explotada de modo irresponsable por muchos gobiernos), reemplazando de hecho la labor democrática y deliberativa de los Congresos, virtualmente vaciados de sus funciones legislativas constitucionales (tomar deuda externa, acuerdos de comercio, etc.) que son subrogadas por los presidentes, que gestionan al Estado como CEO's de empresas, como si el Estado fuera una pirámide, no un balance entre poderes representativos, que conforman todos (no solo el ejecutivo) el Gobierno del Estado. Tendemos a pensar (otro de los prejuicios propagados por los medios, como el anti garantismo inconstitucional, una retórica anti liberal que viene de tiempos del Proceso) que el Gobierno lo ejerce solo el Poder Ejecutivo, cuando no es así. De este modo, se afecta la representación política. Paradójicamente, luego estos mismos gobiernos (que denuestan las garantías penales y sociales y humanas) reprimen la protesta popular y las formas criticas de participación politica y ciudadana, que son el normal resultado del no funcionamiento de las instituciones representativas ("normales"), por ejemplo del Congreso de la Nación. Como en tantos otros campos, se reprime y criminaliza la respuesta social, sin analizar nunca lo que la origina, su causa. 
responsabilidad de un teórico de Kiel como es Alexy), que es, como dijimos, positivista: defiende la legalidad en forma estricta. La dicotomía metodológica no puede ser hoy más clara. El garantismo es positivista: defiende las garantías positivas de nuestra constitución. El no garantismo es no positivista: se aleja de las leyes constitucionales. Por eso es neo constitucionalista. Porque expresaría un ideario novedoso y no positivista, que pone en el centro de la argumentación constructiva, que apoya la labor judicial neo constitucional. No es casual que mientras muchos tribunales apelan a esta nueva tendencia, los gobiernos reproduzcan un discurso anti constitucional, anti garantista, anti garantías constitucionales, sociales, represoras de la protesta o de recorte de los derechos de los trabajadores. Que estigmaticen el satanismo procesal y penal, que es la base y el cuerpo de nuestra primera norma. Nuestra constitución, al tiempo que se materializan programas de ajuste en lo económico y social. Se recortan las garantías de ambos lados. En dos sentidos. Se recorta la igualdad, otro principio basal del derecho. La igualdad ante la ley, ante el Estado. La igualdad en democracia. Esta igualdad demanda en forma urgente hacer operativos derechos que a menudo quedan en los papeles: derechos a educación, a una vivienda, a un trabajo, a comida, a salud de calidad. Para una mayoría de latinoamericanos, estos derechos no son operativos. Esto es: no son derechos a secas. Son ilusiones "no operativas". Es allí donde la justicia podría ser más activista y activa: en la operativización de los derechos sociales. En la justiciabilidad de los derechos económicos y sociales, hoy denegados, recortados. La crítica al garantismo penal y procesal es parte de este proceso de "ajuste". De empobrecimiento. En dos sentidos: porque las garantías sociales son parte de una teoria igualitaria del Estado, que el garantismo defiende como filosofía. Y como critica de las garantías penales y de la no criminalización de la protesta social, que el garantismo defiende como política. En los dos sentidos se ataca públicamente (con claros intereses económicos) el garantismo y a los jueces que lo enarbolan, defendiendo la constitución positiva, escrita y liberal: positivista estricta. Las garantías de la constitución liberal de Alberdi (en Argentina) expresan el núcleo duro del positivismo ${ }^{16}$. El

16 No hace falta mencionar que en la Argentina hubo otra constitución con impronta social - la constitución de 1949- no positivismo expresa la politización de la justicia. Y no al revés, como muchas veces se repite en forma socarrona y a la vez no desinteresada en los medios. En el fondo se quiere cuestionar al garantismo social y penal porque éste pone un "límite" a la represión y al ajuste económico y social, dos caras de un mismo proceso de recorte de garantías, económicas, sociales, procesales, penales, jurídicas en suma. Pero no es poco lo que hay presupuesto detrás del garantismo, por eso presentado como teoría constitucional -y no solo penal- por Ferrajoli ${ }^{17}$. Son dos caras de

que fue derogada en forma ilegal por un bando militar de un gobierno de facto. Curiosamente estos sectores son los que luego hablan de respeto a las "instituciones". De seguridad "juridica", entendiendo por tal seguridad para las inversiones, no para las personas, cuya seguridad social cotidianamente se recorta. El ataque al "garantismo" es parte de ese recorte (de derechos y garantias económicos, sociales, humanos), avalando luego la criminalización de los reclamos y protestas, cuestionando por "garantistas" a quienes, precisamente, defienden a los sectores sociales criminalizados. A los pobres cosntruidos como "delincuentes". Para ello la doctrina penal critica desarrolla, entre otros, el concepto de culpabilidad por vulnerabilidad, un concepto penal orientado a ser una herramienta para los jueces, un instrumento para que la jurisprudencia pueda combatir (e invertir) la selectividad punitiva. Como todo combepto crítico, la culpabilidad por vulnerabilidad pretende ser una herramienta. Véase Discurso de Raúl Zaffaroni en la aceptación del Doctorado Honoris Causa otorgado por la Universidad de Macerata (Italia), 2002. Culpabilidad por vulnerabilidad.

$17 \mathrm{He}$ sostenido en otros trabajos una crítica a Ferrajoli por hacer del garantismo una "teoria" o una "posición doctrinaria" entre muchas, cuando el garantismo expresa, luego de la constitucionalización moderna, el Derecho positivismo mismo, no debiendo tener otro nombre más que ese: Derecho (Constitucional). Entiendo de todos modos que esta critica era apresurada e injusta, ya que incluso el Derecho se recuesta siempre sobre doctrinas. El riesgo, sin embargo, es confundir un debate doctrinario constitucional o penal con la aplicación "no positivista" del Derecho. Esto último es lo que los doctrinarios no solo no deben legitimar, sino que no deben permitir que los jueces emplen sus argumentos de doctrina para alejarse del derecho escrito, como si el garantismo fuera parte de algun "debate" teórico, cuando no es asi: es el texto escrito de nuestra constitución liberal. Nuestro derecho positivo. Esta era la prevención que queriamos dejar asentada, cuando deciamos que el garantismo no es una doctrina. Del mismo modo, Zaffaroni ironiza cuando responde a sus detractores anti "garantistas", que él no es "garantista", que la "garantista" es la Constitución argentina de Alberdi. Con lo cual la llamada "doctrina Zaffaroni" (por Patricia Bulrich) puede ser bien renombrada Doctrina Alberdi. Pero en el fondo de lo que se trata no es de un debate entre doctrinas, sino de la constitución, que es una norma obligatoria y primaria. No una teoria juridica discutible entre otras. Son dos planos que deben ser muy bien diferenciados, en momento en que se alimentan confusiones legales nada inocentes, que siempre disimulan intereses concretos, no siempre asumidos, pero que a la larga siempre terminan precisamente en un recorte directo de garantias, en un recorte de derechos sociales y económicos. En un "ajuste". El "garantismo" si se lo toma como filosofia igualitaria, es lo anverso de un "ajuste" de derechos (mal llamadas "oportunidades") El derecho, en todo caso, se haya más proximo a la noción de capacidad (Nussbaum-Sen) que a la remota e impersonal noción de "oportunidad" de libre mercado. Creemos en la igualdad de derechos, no sólo en la igualdad de oportunidades. Para que haya igualdad de oportunidades, tiene que haber igualdad de derechos. En caso contrario, se naturaliza y legitima la 
un mismo proceso económico y social. Por eso la crítica al garantismo tiene muchas caras: no solo una. No podemos detenernos en responder cada una. Esperamos que otro autor pueda encarar esa tarea con sistematicidad. Sería un aporte en la doctrina contemporánea. Seguir enfatizando y remarcando la importancia del paradójicamente cuestionado (por medios que fueron cómplices del Proceso en Argentina) garantismo penal ${ }^{18}$.

\section{LA ASOCIACIÓN ILÍCITA, UN TIPO PENAL DE CONSTITUCIONALIDAD DUDOSA}

Entendemos que la asociación ilícita es un tipo penal de constitucional dudosa, cuya historia misma expone sus intereses: combatir toda asociación política, toda asociación gremial, toda agrupación que de forma a una protesta organizada, articulada políticamente. Este tipo es precisamente empleado para criminalizar cualquier agrupación opositiva, que hace política. Se criminaliza la protesta, pero también la participación política. Y se criminalizan no actos, sino intenciones supuestas, basadas en un principio que no rige el ordenamiento argentino y expresa el derecho penal anti liberal de autor, no de acto:

desigualdad -desigualdes atroces, criminales- en nombre del "mérito".

18 No se equivocan el profesor peruano Gino Ríos Patio y el colega limeño Renzo Espinoza en denunciar el paradigma inquisitivo vigente en nuestro sistema de (administración de) justicia. Los medios argentinos califican de "polémicos" a los jueces que defienden los derechos sociales y económicos (Clarin, foto de Zaffaroni con el Papa Francisco, en tapa, día 4 de Julio 2019), como derechos (garantias) que deben ser plenamente operativos y eficaces. Esto es polémico. No es Polémico, sin embargo, ningun juez que libera a policias sospechados de asesinar personas. Esa violencia se justifica mediáticamente, atacando, a la inversa, a la justicia garantista, que defiende delincuentes. No es un doble estandar: es la legitimación no positivista de la erosión continua del Estado de Derecho, en nombre de alejadas teorias alemanas, pensadas tal vez con razón pero para otra realidad social e institucional y otro contexto regional, pero que en nuestro contexto, donde la defensa del positivismo constitucional resulta critica y de verdadera urgencia, resultan funcionales - sin pretenderlo, sin dudasal no garantismo más retrogrado y conservador (que no es el objetivo de Alexy, naturalmente, mientras escribe en el norte de Alemania). Son polémicos los jueces que respetan la constitución. No son polémicos, paradójicamente, los jueces afines (dóciles y permeables a la presión mediática) que dictan por millares ilegales presiones preventivas sin condena, violando la presunción de inocencia. Esta ilegalidad cotidiana, que alcanza a casi el $60 \%$ del total de personas privadas de su libertad en forma ilegitima e inconstitucional, no es presentada como polémica. Está bien que estén presos en cárceles degradantes. Sin garantías... Sin respeto de la constitución. Sin garantismo. Se justifica la tortura implicitamente. La tortura institucional e institucionalizada, como práctica normal. Y a quien la cuestione en nombre de los derechos humanos, se lo acusa de ser garantista o defensor de la "Doctrina Zaffaroni". el principio de "peligrosidad". Se juzga a una persona por ser (peligrosa), no por un hacer algo concreto, como manda el derecho penal de acto. La asociación ilícita tiene pues varias fallas conceptuales. Es un delito en grado de tentativa. Es un tipo penal autoritario, que busca criminalizar asociaciones gremiales o estudiantiles.

Entendemos a la asociación ilícita como falso tipo penal. Decimos que es falso, además de inconstitucional, porque la aplicación del mismo presupone un error lógico, hablando en términos de lógica formal: cuando se la aplica, se cae en un razonamiento, como veremos, inválido. La inconstitucionalidad va por un lado, la irrazonabilidad jurídica, por otro.

La asociación ilícita es un tipo penal abiertamente inconstitucional porque viola el principio de lesividad, base del derecho penal, de dos maneras diferentes. Primero, porque es un delito de peligro abstracto, esto es, se procesa a alguien por su mera (incomprobable y siempre basada en una arbitraria sospecha) peligrosidad, algo vedado por nuestro ordenamiento (aunque no en otros, como el ordenamiento chileno, que aun la conserva; en Argentina se lo ha usado históricamente para perseguir gremios y agrupaciones estudiantiles o culturales opositores como asociaciones ilícitas y peligrosas), y segundo, porque la misma se consumaría sin lesión alguna (o en cuyo caso la ejecución es un crimen independiente y tipificado, pero distinto de la mera asociación ilícita), lo cual viola la lesividad en sentido directo, por un lado, y también el debido proceso, que prohíbe ser procesado dos veces por el mismo hecho, por el otro (Ruconi, 2018) ${ }^{19}$.

\footnotetext{
19 Dossier Imputado Colaborador. La asociación ilicita es presentada por muchos autores como un tipo penal inconstitucional. Del mismo modo, puede pensarse que la figura del arrepentido al forzar declaraciones por via indirecta (coactiva, bajo la amenaza del uso ilegal pero normalizado y extendido en el ordenamiento argentono de la prisión preventiva sin condena, violando la constitución) es también un tipo inconstitucional (amén del estado degradante de las cárceles, algo también señalado por la propia Justicia). Ambos son empleados en la actualidad en diversos procesos penales, la figura del "arrepentido" y la figura de la "asociación ilicita" van de la mano para criminalizar a todo un gobierno: se buscan "arrepentidos" (funcionarios o no) de haber integrado un gobierno que es absdurdamente calificado de "asociación ilicita". Lo que en Peru se denomina "imputado colaborador", o "colaboracion eficaz", en Argentina ha sido regimentado con la nueva ley del "arrepentido", leyes con claro miramento politico, leyes hechas casi con nombre y apellido, que tienden a dotar a la justicia de nuevas herramientas (arbitrarias, inconstitucionales) en procesos direccionados politicamente, selectivos, y donde los supuestos "arrepentidos" siempre
} 
La asociación ilícita termina configurando un delito de mera voluntad, previo a cualquier tentativa, que violenta el principio de lesividad en dos sentidos diferentes.

declaran en una sola direccion, siendo "premiados" cuando así lo hacen, cuando lanzan cualquier imputación criminal a la ex presidenta Cristina Kirchner. Alli reciben un "premio" (que en rigor debiera configurar un derecho básico), que es esperar la condena en libertad, no en prisión preventiva ilegal. Este "premio" convierte en "beneficio judicial" arbitrario y discrecional de los jueces (los dota de poder de "negociar" con los imputados) algo que en rigor debiera ser una norma procesal. Implica un deterioro del ordenamiento jurídico argentino. Un deterioro institucional, hecho, como siempre, en nombre de la salvaguarda de las instituciones. Autores como Julio Maier o Marcelo Sancinetti, dos penalistas procesalistas que suelen ser dispares en sus posiciones, coinciden sin embargo en cuestionar la nueva ley del arrepentido en Argentina, una ley (ad hoc) que termina abriendo la puerta a la coacción judicial sobre los imputados para que se auto-incrimen, algo vedado por nuestra constitución. El corazón de esta estrategia es la naturalización (como práctica de "negociación") de algo (ilegal, como es la prision preventiva, devenida norma, para que se "confiesen" los imputados encerrados en celdas degradantes, no muy diferente de prácticas medievales con presos que eran torturados para arrancarles una confesión, un "arrepentimiento", una información útil sobre su "pecado" de "brujeria" o magia negra, su corrupción capital) que debiera consistir en un derecho y hoy es visto como un mero "beneficio" arbitrario (y poco objetivo): la excarcelación durante el proceso, el uso discrecional ilegal, y extorsivo- de la prision preventiva, empleada por muchos jueces y fiscales como arma (inconstitucional) de negociación con (coacción sobre) los imputados presos, ya privados inconstitucionalmente de su libertad, lo cual los coloca bajo presión de (ser "arrepentidos", declarando en su propia contra, para "beneficiarse": se beneficia a un imputado a la vez que se lo premia por quebrar su propio derecho constitucional básico a no declarar contra sí mismo). Por eso entendemos que la ley del arrepentido, funcional a los procesos donde se criminalizan gobiernos enteros (opositores) como "asociaciones ilícitas" (algo propio del neo neoliberalismo, donde todo Estado, todo gobierno que hace politica, es populista" y por ende, siguiendo a José Luis Espert, a fin de cuentas, una "asociacion ilicita", una "banda de criminales", una banda de "corruptos"-siendo que la corrupción como término también tiene una historia vinculada a la aristocracia que no debiera perderse de vista, como recuerda Eugene Weber, la polícita como participación social misma es "corrupta" (es "brujeria" criminal de indios y yeguas) para el financierismo neoliberal tecnocrático y pulcramente administrativo con sus impolutas planillas de excell, que no admiten discusión ni discursos "oscuros" de "política"- expresiones que surgen en los medios de modo desembozado, pero luego son retomadas por nuestra justicia "independiente", que no hace "politica", que no recibe "presiones", que juzga de modo pretendidamente "imparcial") es una ley inconstitucional. No es casual a su vez que Milagro Sala en Jujuy, opositora (indigena) también haya sido procesada -y encarcelada sin condena en 2016bajo esta figura: la asociación ilícita, subversiva: Sala es una mujer negra, colla, pobre, una "bruja", que expresa la "corrupción" social y política. Por eso se la encarcela, y fue apresada antes de cualquier condena, antes de cualquier proceso, de modo ilegal. Sin garantías. Sin "garantismo". Los medios apoyaron este proceso, como apoyaban la caza de brujas en la Edad Media. La Inquisión no ha terminado. La colonización cultural y económica tampoco. Nuestra realidad sigue siendo la dependencia cultural y financiera de las casas matrices, que dictan con su realismo (económico y jurídico, no positivista) quién debe ir preso y quién no. El proceso es secundario. Es una mera formalidad... (crecientemente arbitaria, anti garantista y vacia, "realista", no positivista, sin apego a norma procesal alguna) Croxatto (2018).
La asociación ilícita esconde, si se la mira con atención, una petición de principio: no puede probarse, y como tipo penal, en consecuencia, es inconstitucional, porque se referiría, de existir, solo a acciones privadas exenta de la autoridad de los magistrados, Por eso se habla de peligrosidad en sentido abstracto (detrás de esta peligrosidad abstracta está siempre escondido el móvil político). Esto mancilla el principio según el cual la pena sobrevienete solo cuando existe una lesión a un bien jurídico concreto. (Esto diferencia al delito del pecado, el Derecho de la Moral). Los procesamientos bajo esta figura siempre se suceden por un crimen independiente (o paralelo) a la asociación ilícita misma, algo que enseña muy bien Zaffaroni, lo cual conduce a duplicar procesos, condenado o procesando personas más de una vez por un mismo delito (en momentos en que, como enseña Agamben (2000), la verdadera pena es el proceso, no la condena). Los que son ilícitos son los actos tipificados como tales y que causan lesiones concretas a bienes jurídicos protegidos (no a deberes morales abstractos). Pero ninguna asociación lesiona un bien jurídico por el mero hecho de ser una asociación (política). Esta lesión no puede ser "abstracta", como quieren los regímenes totalitarios, como el nazismo o la dictadura argentina, que perseguía asociaciones ilícitas y peligrosas (asociaciones políticas) por el mero hecho de ser tales: libres manifestaciones políticas (o de otro tipo, estudiantes, sindicales) de personas que se asocian, se juntan, se reúnen libremente. La asociación, como muestra Weber en sus trabajos, es política por definición. Hoy parece haberse reemplazado analíticamente el par asociación política por asociación ilícita. Un vocablo reemplaza furtivamente al otro, no explícitamente o de manera compacta, pero si en el ideario y vocabulario político público. No son accidentes ni exageraciones semánticas o semióticas (hemos aprendido con Pavarini que a veces es prudente aprender a exagerar, es un buen ejercicio, porque lo que luego nos dejan tales exageraciones es un campo de conceptos críticos que muestran crudamente una realidad dolorosa, mostrando que la teoría no era nada exagerada, no era ni representaba, como muchos consejos de Zaffaroni, una exageración en absoluto). Porque el lugar de la política es impugnado precisamente por gobiernos neoconservadores, que tachan a gobiernos enteros (muy politizados) de ser asociaciones 
políticas llamadas asociaciones ilícitas. Existe un cruce retórico que excede pero abarca al campo legal. La categoría asociación política parece hoy reemplazada en el diario colectivo mediático judicial conservador pro neo liberal por la categorización asociación ilícita que se aplica sobre todo para perseguir gobiernos populares (y políticos), presentándolos, como en épocas de dictaduras, como asociaciones irregulares, politizadas, ilícitas y criminales. El paso de un concepto a otro, el predominio de una voz nueva (ahincada en los procesos judiciales, que ocupan las tapas de los diarios) no es casual. Donde antes se hablaba de asociación política, hoy se habla de asociación ilícita, en tiempos de gobernanza (que reemplaza hasta la noción misma de gobierno político). Estos son los modelos pro libre mercado, la lectura neoconservadora, calificada por Ffrench-Davis de financierista.

Cuando la justicia prueba el plan sistemático de robo de bebes, prueba tal plan desde su cabeza, mostrando el plan estructurado que los distintos actores, fuera cual fuere su puesto, obedecían. No se habla sin embargo (doble estándar estridente) de la dictadura argentina como de una asociación ilícita. Se prueban crímenes concretos, en funciones de graves y concretas (nada abstractas) lesiones a bienes jurídicos. Pero si se usa esa categorización dudosa (mediática y judicial) para descalificar a todo un gobierno también acusado, como el Lula de Brasil o el Ecuador de Correa, de populista. Lo populista y lo ilícito van de la mano. La criminalización de ideas políticas cuyas asociaciones se criminalizan, como en épocas pasadas, no democráticas, donde todo opositor era perseguido, criminalizado, silenciado. Para que no hiciera política, precisamente, diezmando su asociación por ilícita. La criminalización de asociaciones supuestamente ilícitas esconde casi siempre un claro objetivo político: diezmar opositores, criminalizarlos. Estigmatizarlos como ladrones que conformaron una asociación irregular. Es un proceso que no se observa solo en Argentina, sino en muchos otros países de la región y del mundo. Aquellos gobiernos que se alejan de la tónica neoliberal -factótum de las instituciones financieras internacionales (cuyos crímenes de cuello blanco quedan en las sombras)- y hacen en consecuencia política, son estigmatizados (populistas) cuando están en el poder, y perseguidos (por ser asociaciones ilícitas) cuando dejan de estarlo. Por eso se estimula, para exaltar la persecución judicial con gran aparato de show mediático (lawfare, guerra jurídica, un oxímoron que repetimos como si tuviera sentido, como el de derecho penal humano) horadando toda garantía (anti garantismo procesal penal), la figura de los arrepentidos. Arrepentidos de haber conformado un gobierno popular, populista. De eso, en última instancia, se tendrían que arrepentir. Son forzados públicamente a ello, lo cual, naturalmente, es inconstitucional, porque viola la obligación de no forzar a nadie a declarar contra sí mismo, sin ejercer, como hasta Sanchinetti reconoce, coacciones (con el agravante de que son coacciones judiciales, de quienes debieran preservar la legalidad del proceso) indirectas, a través de supuestos premios para quien se arrepiente y confiesa. Esto es y representa una extorsión instrumentada, paradójicamente, en forma criminal, desde el poder judicial mismo, que instrumenta algo ilegal (la amenaza de la prisión preventiva ilegal, que debiera ser la excepción y no la norma, y nunca el producto de una negociación o pacto con imputados, sino de una fría ponderación legal y objetiva, técnica, no negociada) para arrancar confesiones que violan la integridad y los derechos del imputado. Es una coacción grave sobre su persona, para que confiese, para que colabore y se beneficie. No muy distinta de los mecanismos de tortura para arrancar confesiones en tiempos de dictaduras. Para obtener beneficios para quien habla y declara contra sí y contra terceros. Delaciones premiadas. Otro mecanismo de deshumanización de nuestro sistema penal. No es el único ${ }^{20}$.

La asociación ilícita además se presume $a$ posteriori: peor en todo caso, debe ser probada (para existir en cuanto tal), con prescindencia de los actos que hoy se imputan (como su base), y esto es precisamente lo que la justicia no puede ni pudo nunca hacer: probar la asociación ilícita por si sola, por si misma, en cuanto tal (por eso se está al borde de caer

20 Véase Croxatto, G. L. "La muerte de la Convención de Ginebra". Y también "Una critica al lenguaje (nuevo) de la gestión carcelaria". Ambos en prensa. Revista Lecciones y Ensayos, y Revista Pensar en Derecho, UBA-Derecho, Buenos Aires. 
en el absurdo de imputar a todo un gobierno como una asociación ilícita en Argentina ${ }^{21}$ ) con independencia de las denuncias de las fotocopias. La asociación ilícita es una figura penal inconstitucional y persecutoria, que han empleado casi todos los regímenes dictatoriales para acallar opositores, por el mero hecho de serlo: por el hecho de estar juntos ("asociarse") eran "ilícitos", y peligrosos, pero con prescindencia de su conducta ilícita o adicionalmente a ella, ya que la conducta ilícita configura siempre (cuando existe) otro delito que se prueba con independencia de la asociación en cuanto tal. Si no se puede probar la asociación ilícita sino por delitos distintos de ella misma, como pretende hacer el juez Bonadio, al aplicar esta figura se termina barriendo con la legalidad y el debido proceso.

La asociación ilícita es inconstitucional, y además, como concepto jurídico, esconde una petición de principio, que es formalmente insuperable en democracia, ya que la única manera de superar esa petición (ese vicio procedimental o lógico) es, como en los casos históricos más próximos, mancillando

21 Parte de la justicia argentina replica expresiones mediáticas de candidatos políticos neoliberales, como el candidato Spert, que acusa a todo el gobierno anterior de conformar, en su prédica ultraliberal privatista, una "asoacion ilicita". No muy alejada de la posición de Friedman, de enorme repercusion en Chile. En elf ondo, no estamos lejos para que se califique desde el neoloiberalismo no solo a los gobiernos (politicos populistas, todos sinonimos) sino a los propios Estados como asociaciones "ilícitas", "elefantes", del "gasto" inútil. Son los mismos sectores que analizan las campanas y votaciones democráticas en términos de cuántos nos cuestan (cuánto nos "cuesta" ejercer nuestros derechos civiles) el economicismo es otro de los arietes actuales para recortar derechos y garantias sociales, laborales, sindicales, estudiantiles, previsionales, no solo procesal-penales. No casualmente el termino "asociaciones cooperativas" es empleado por Berenstein para caracterizar todo movimiento al "socialismo" político. No casualmente gobiernos neoconservadores, neoliberales, con logicas totalitarias y anti participßación politica, denuestan la politica y emplean esa catehoria (la de asociacion ilicita, propia de epocas no democraticas ni liberales ni en lo polico ni en lo economico) para denostar mediaticamente y luego criminalizar judicialmente (por que muchas veces nuestros tribunales se mueven al calor de la agenda publica mediatica politica y no por estricto criterio juridico constitucional) de "asociaciones ilicitas" populistas, "politizadas", criminalizando gobiernos populares, aprensado o persiguiendo a sus lideres populistas politicos populares: Lugo, Correa, Lula, Cristina, son solo ejemplos. Este lenguaje y el empleo de esta figura (asociacion ilicita, bvanda de ladrones...) para criminalizar, en tiempos politicos neoconservadores en la region, a lideres de gobiernos populares (calificadores por los acotilos neoliberales de la gobernanza anti politica) de asociaciones ilicitas, no es un accidente. Lo ilicito en el fondo (de alli la emergencia de la gobernanza) es el hecho de la politica, de hacer politica y de tener gobiernos politicos. La ilicita -la corrupta- es la política. No el libre mercado. Siempre puro, neutral, eficiente. Sin criminales. La construccion de estos lenguajes es progresiva y termina llegando a los medios y a los tribunales al mismo tiempo. Son procesos colectivos. Véase Berenstein 1998). la lesividad, probando que la misma produce lesiones punibles que son "abstractas", no concretas. Que ataca la "moral". No el Derecho positivo. Por eso es una figura que emplean los regímenes autoritarios, que persiguen y acallan el disenso ${ }^{22}$.

La asociación ilícita no puede probarse, y se mancilla, cuando se la pretende usar para encarcelar opositores, el elemental principio de lesividad, porque se apela a la misma, pero se la prueba por hechos anexos que tipifican delitos distintos de ella misma, lo que viola (aunque esto sea para muchos un salto lógico sutil, ajeno a la guerra mediática, apéndice de la jurídica) el principio de legalidad, esto es: nuestra constitución. La asociación ilícita es, en consecuencia, un tipo penal inconstitucional, que debe ser derogado, porque es instrumentado en todas las épocas para estigmatizar y perseguir a opositores políticos, en función de un derecho penal de mera voluntad (violando el principio de lesividad), como el derecho penal nazi o la (In)Justicia argentina durante el Proceso. Es una figura propia del derecho penal de autor y no de acto, como exige nuestra democracia constitucional. Es el derecho penal del enemigo de Jakobs, célebre en Bonn, pero también en muchos centros conservadores de pensamiento funcionalista latinoamericano, que reproducen en Perú o Argentina doctrinas generadas en el frío norte europeo ${ }^{23}$.

22 Otra de las caras del no positivismo. Otra de las facetas o matices del discurso de recorte de garantías, de la crítica ruin del garantismo constitucional y procesal-penal.

23 Una frialdad que, como muestra Adorno, tiene muchas caras y esconde muchos crimenes, esconde una lógica (funcional para el capitalismo financiero y sus crimenes trasnacionales, porque los flujos pueden viajar con libertad, mientras las personas se ahogan de a miles, ante la indiferencia de las democracias civilizadas) que subyace y permanece aun impregnando al Derecho y a la sociedad en su conjunto. Adorno (1992, pp. 361-373. Adorno toma en cuenta, rescata, como Jean Luc Nancy (en La representación prohibida), el célebre discurso de Himmler a los soldados alemanes, ante fosas abiertas con cadáveres apilados, cuando enfatiza que hace falta "endurecerse". Volverse más "duro". Este "endurecimiento" no era solo para los soldados, ahora lo sabemos: era para todos. Para todos los que hacen -como cualquiera de nosotros, un trabajo común. No solo Eichmann, sino cualquiera, como dice Boll, como dice Bauman, que hace sencillamente su "trabajo". Todos tenemos la mano manchada con sangre. (Bauman, $Z$. Modernidad y Holocausto. Ed. Sequitur. Madrid. 1999. Cap. 2. Bauman habla de modernidad y Holocausto: el Holocausto no es algo externo a la modernidad, es parte inseparable, inherente, de ella. Mismo argumento de Adorno en su crítica a la modernidad instrumental, a la razón ilustrada, con el avance de la técnica y la indiferenciación entre las personas, con el auge del lenguaje "administrativo", con el olvido del otro como requisito para que la sociedad industrializada pudiera funcionar de modo "eficiente". Adorno extiende las críticas a la modernidad con sus supuestos "derechos", misma critica que habia trazado Nietzsche al humanismo teórico. Nietzsche ve una contradicción en este humanismo 
Puede concluirse que la figura de asociación ilícita (asociación subversiva, como rememora Silvia Federici) va de la mano de la ley del arrepentido y de delitos absurdos como el delito de traición a la patria, todos con la misma raigambre persecutoria, inquisita, anti liberal, nada republicana, empleados para estigmatizar opositores o perseguirlos, silenciarlos. Para el caso mucho más grave en términos de traición es el sobreendeudamiento criminal de los estados emergentes, que condenan a la miseria planificada a millones de hermanos latinoamericanos. Esta miseria planificada no se criminaliza, el hambre no se juzga, (se naturaliza como producto natural y libre del mercado) pero conforma prolijos planes de gobierno o como se dice ahora, de gobernanza. Hay actos concretos, hay responsabilidades penales detrás de estas políticas macroeconómicas fraudulentas. Hay estafas masivas, enormes fraudes jamás juzgados. Jamás nombrados. Pero cuyo resultado lo pagan los que caminan kilómetros juntos a sus hijos para comer en los basurales. Quienes venden estampitas en los trenes. Quienes duermen en la calle. Los que no tienen voz ni derecho.

\section{LA PRISIÓN PREVENTIVA: DE EXCEPCIÓN A NORMA ILEGÍTIMA}

Vivimos en la Argentina la triste realidad de procesamientos y prisiones preventivas arbitrarias impuestas a personas de la oposición, como resultado del ahora mundialmente llamado lawfare o guerra judicial, es decir, de persecución y producción de presos políticos como fabricación del enemigo al mejor estilo de lo peor de Carl Schmitt, con Milagro Sala como caso más paradigmático y aberrante a la cabeza $^{24}$.

"teórico". Por eso las comillas. Adorno también. Nosotros somos herederos de este proceso, no ha terminado, por eso los genocidios se siguen cometiendo: porque la lógica que los produce sigue viva, sigue vivo el "concepto" de Auschwitz, como remarca Adorno, una sociología del poder punitivo, como pide Zaffaroni, implica hacer una sociologia del Holocausto, por eso penalismo contemporáneo hunde sus fuentes, sus raices, en el penalismo alemán nazi. Véase Zaffaroni, E. R. Doctrina Penal Nazi. Ediar. Buenos Aires. 2018. También Nietzsche, F. El nacimiento de la tragedia. Alianza. Madrid. 1998).

24 No debe olvidarse que Carl Schmitt fue un continuador de la crítica antiliberal (que en Alemania tuvo una larga historia política) en el plano del penalismo, centrando parte de sus objeciones en el liberalismo (denostado por abstracto) de Paul Anselm von Feuerbach, redactor del código de Baviera de 1813 y uno de los padres fundadores de la legalidad penal moderna, a la que convirtió en un principio institucional básico del Estado de Derecho Schmitt (1996).
Esto nos pone de cara a dos sentidos del uso del derecho: uno, el sano, como medio de coexistencia democrática y pacífica, es decir, racional, en el marco de un Estado más o menos de derecho; el otro, el perverso, como medio de ejercicio del poder arbitrario hegemónico, irracional, como pulsión de un Estado de policía.

El último era el único que consideraba el viejo marxismo, pero como todavía quedamos quienes creemos en la posibilidad del primero, entendemos que debemos seguir empujando al Estado de derecho para tratar que todos seamos lo más iguales posible ante la ley; los que ahora impulsan el segundo, tratan que todos estemos sometidos a la voluntad arbitraria del que manda.

Cada jurista elige de qué lado quiere estar. Algunos prefieren no elegir y hacerse los distraídos. En este último caso también eligen el lado peor. Como siempre, la elección tiene sus costos: unos son satanizados por los medios monopólicos del lawfare, pero duermen tranquilos; los otros son alabados como sabios por esos mismos medios concentrados del discurso único, pero toman psicofármacos y racionalizan con mecanismos de huida, al decir de Ana Freud.

Esta irracionalidad represiva - como todo- tiene también algún efecto positivo: las personas legas de nuestros barrios, que nunca se interesaron mucho por el derecho y la justicia, ahora preguntan y abren un interesante espacio de difusión jurídica que antes no existía. Esto confirma que el mal absoluto no existe, o sea, que el maniqueísmo es falso, aunque no por eso legitimemos todo funcionalismo.

Una de las preguntas más frecuentes es cómo se inventan tantos procesos penales, y es a esto que queremos responder aquí, con la brevedad del caso. Explicaremos el sencillo método perverso que se usa, aprovechando algún resquicio no del todo esclarecido de nuestra doctrina jurídica de siempre y de la anárquica jurisprudencia de nuestros tribunales.

Nunca tuvieron muy en claro nuestros doctrinarios (autores de libros) cuándo hay un único delito y cuándo varios delitos, lo que se reflejó sobre las decisiones de nuestros tribunales que, como se sabe, son caóticas, porque si bien tenemos un único código penal, hay tantas interpretaciones posibles 
como fueros (federal, provinciales y de la CABA), sin que nadie unifique los criterios de interpretación judicial.

Es decir: cada juez puede echar mano con total libertad de la interpretación (Fuller, 1999) ${ }^{25}$ que

$25 \mathrm{El}$ positivismo pedia jueces capaces de aplicar más que de interpretar (con el subsiguiente riesgo de discrecionalidad) el Derecho. El porobkema de la interpretacion juridica (generadora de falta de certeza y precisubilidad, afectando la publicidad misma del derecho positivo, la seguridad juridica) ha perseguido y aun obsesiona a los jurisconsultos. Pero el neoconsittcionalismo, cuando propone alejarse del positivismo, esta avruiendod emasiado el abanico de actividad judicial, afectando el normal equilibrio entre podereses. Actualmente percibimos detras del activismo juducial conservador, una fuerte crisis de la vieja doctrina republicana de pesos y contrapesos, de balances y frenos entre poderes del Estado. El activismo judicial puede ser una consecuencia, y no una causa, de este fenomeno. Tenemos poderes cerrados sobre si, congresos que fungen de escribanias, presidentes que sibrogan al congreso con decretos de necesidad y urgencia que han perdido troda excepcionalidad y se emplean en circunstancias normales, habituales, (pero avasallando al Congreso y sus prerrogativas, que quedan diluidas, el congreso argentino es un perfecto ejemplo de este vaciamiento politco, la deuda externa o los acuerods militares o econoimicos deben ser decididos en el congreso, pero hace tiempo que nos on decididos por este y ni siquiera el ejecutivo busca que el congreso conozca sus implicancias, diretamente no le traslada esto, que es o debiera ser en circunstancias normales su principal funcion constitucional, hoy mancillada y herida), y el poder judicial, que en muchos casos reproduce intereses del poder politico de turno, mostrando falta de imparcialidad e independencia, siendo cooptado por estructuras que minan su funcion primorcial, que es preservar las garantias constitucionales, hoy socavadas. Existen ejemplos de procesamientos politicos en tiempos electorales que luego encumbran al juez que los llevo adelante, recibiendo como premio politico un cargo precisamente ministerial del principal beneficiado de ese procesamiento. El gobierno de los jueces no parece una buena salida para una democracia, aunque puede expresar un avance de la constitucionalizacion y la eficacia directa de nuestras constituciones. Si todo se haya ya constuticionalizado, entonces la ley -la norma escrita, positiva- pierde importancia, se diluye su peso, y tambien el de las admkinistraciones publicas: todo el "peso" o responsabilidad pasa a la justicia, principal encargada de operastivizar esos derechos ya reconocidos y con plena jerarquia constitucional. Por eso entendemos que el activismo judicial no es siempre responsabilidad de los propios jueces ni expresa siempre un burdo afan de protagonismo de éstos. Expresa una dinamica institucional de la que el neoconsittucionalismo es en parte responsable. Porque el constitucionalismo precisamente traza fuertes limites a la soberania politica, y al funcionamiento de nuestras instituciones democrácias. La esfera de lo indecidible es un buen ejemplo de limite al poder soberano. De limite a la politica. El correlato de esta falta de debate politico, puede ser el traslado de los conflictos a la esfera judicial, donde se dirimen bajo una nueva lógica (constitucional, constitucionalizada, institucionalizada): la judicialización de la politica es pues un resultado. Aunque tenga muchas manifestaciones, existe una lógica que expresa un nuevo escenario de reparto de poder, donde las antiguas funciones de los tres poderes quedan desfasadas (con la crisis de la doctrina de pesos y contrapesos, viejo sostén de toda república moderna, el desface de la doctrina de división de poderes expresa en rigor el descalabo de esta otra doctrina sostén: los pesos y contrapesos no están funcionando como la república con división de poderes presupone y necesita, esta es la crisis detrás de la crisis de la república y el garantismo constitucional). Existe en suma una nueva ingeniera institucional. El neoconstitucionalismo, con la efiucacia directa y horuiozntal de las constituciones, de principios como la digniodad, expresan esta nueva dinamica. más conviene a lo que quiere decidir. Primero decide y luego rebusca en la jurisprudencia y en la doctrina los argumentos: esto suele llamarse tópica y lo permite nuestra anarquía jurisprudencial institucionalizada.

En este caso se echa mano del tipo penal de la llamada asociación ilícita del artículo 210 del código, que pena al que tomare parte en una asociación o banda de tres o más personas destinada a cometer delitos, por el solo hecho de ser miembro de la asociación.

En la versión original del código de 1921, la pena era de un mes a cinco años. Con motivo de la violencia política, en enero de 1974, la ley 20.642 aumentó la pena de tres a diez años y agregó que los jefes u organizadores tendrán como mínimo cinco años. Pasó la violencia política, pero el texto quedó escrito hasta ahora en esos términos. Es decir, que su altísima pena vigente es un resabio de una coyuntura histórica superada hace casi medio siglo.

La primera cuestión que plantea este supuesto delito es su constitucionalidad. Obsérvese que, si tres personas medio alegres con copas se ponen de acuerdo para asaltar bancos, con ese sólo acuerdo se comete el delito, aunque al día siguiente se diesen cuenta de que habían decidido una estupidez y no hiciesen absolutamente nada más. Sólo podrían ser absueltas por inimputabilidad si hubiesen estado del todo borrachos.

Esto es inadmisible, porque ni siquiera se trata de un acto preparatorio y mucho menos aún de una tentativa, lo que se pena es únicamente la idea de cometer los delitos.

En general, los delitos se penan cuando comienzan a ejecutarse, es decir, cuando hay tentativa. Todos los actos anteriores o preparatorios son en general impunes (comprar el cuchillo con el que se piensa amenazar a alguien), porque son equívocos (dado que también se lo puede comprar para comer un asado).

Pero la asociación ilícita ni siquiera pena un acto preparatorio, que recién lo habría, por

Y también expresan sus nuevos desafios. Vease Glendon, M. A. El lenguaje de los derechos. en Revista Estudios Públicos, 70. (1998) tomado de Capitulos 1, 2 y 7 ("The Land of Rigths", "The Illusion of Absoluteness" y "Refining the Rethoric of Rigths") del libro de Mary Ann Glendon, Rights Talk. The Impoverishment of Political Discourse (Nueva York: The Free Press, 1991). 
ejemplo, si comenzasen a proveerse de armas. Y el comienzo de ejecución de la tentativa está aún mucho más lejano de ese mero acuerdo verbal. Semejante adelantamiento de la prohibición no tiene ningún sentido, porque sólo se trata de una exteriorización verbal y ni siquiera se exige ésta en forma expresa, pues bastaría con el simple asentimiento con una bajada de cabeza, con un gesto.

Esto quizá -aunque dudosamente- podría ser admisible si se tratase de delitos de extremísima gravedad (genocidio, liberación de energía nuclear), pero se trata de cualquier delito, lo que lleva a otra irracionalidad: tres mecheras de tiendas se ponen de acuerdo para hurtar prendas de ropa interior de mujer y por ese sólo hecho tienen una pena mínima de tres años y, si una de ellas es la que organiza a las otras dos, de cinco años, pero si sin el acuerdo hurtasen alguna prenda, es decir, cometiesen el delito que acuerdan cometer, la pena no podría superar los dos años (art. 162 del código).

¿De dónde proviene este tipo penal inconstitucional? Su genealogía es, por cierto, muy poco recomendable: surgió en Europa en los tiempos en que la huelga era un delito y tenía por objeto la represión a los sindicalistas. Como redactamos códigos por correspondencia, se incorporó a nuestra ley penal por arrastre.

Pero dejemos de lado su inconstitucionalidad, sólo a efectos de ver cómo funciona en la práctica.

En realidad, hay relativamente pocas condenas por asociación ilícita, pero hay muchos más procesamientos, porque sirve para denegar la excarcelación y dejar a las personas presas durante el proceso (prisión preventiva). Basta con procesar a alguien como jefe u organizador y, conforme al criterio de la grave amenaza de pena que hace presumir la fuga (el llamado riesgo procesal) se lo manda a prisión por años.

Pero hay mucho más que esto, porque también sirve para clonar procesos y prisiones preventivas al infinito.

Aprovechando -como dijimos- que nunca queda del todo claro para la jurisprudencia cuándo hay un delito y cuándo varios delitos, se pasa por alto un argumento irrefutable: cuando tres personas se ponen de acuerdo para cometer delitos y luego en la realidad los cometen, la voluntad de cometerlos manifestada en el acuerdo es la misma que se materializa en la comisión. Así, la voluntad de asaltar bancos se materializa en los asaltos que los delincuentes cometan luego. Hay una única voluntad desde el acuerdo hasta la comisión del crimen y no se la puede dividir. Esto hace que la asociación ilícita y los delitos que se cometen luego conforme a su finalidad sean un único delito, un único hecho. Técnicamente a esto se lo llama concurso ideal, en tanto que a toda pluralidad de delitos por los que deba condenarse en una única sentencia se lo llama concurso real.

Basta con ignorar este argumento básico y elemental para desdoblar el hecho único en tantos hechos como supuestos delitos se quieran imputar a un procesado como cometidos por la asociación ilícita, para clonar procesos al infinito $\mathrm{y}$, mucho más, si en cada uno de ellos se reitera el procesamiento por la propia asociación ilícita.

La amenaza de pena con este razonamiento y el número de procesos y sus respectivas prisiones preventivas llegan a montos siderales, porque la pena para el hecho único es la más grave entre todas las previstas, pero en el concurso de varios hechos en una sentencia las penas se suman, según algunos -y la ley del falso ingeniero Blumberg- hasta cincuenta años, aunque el genocidio tenga pena máxima de treinta, lo que parece que tampoco llama la atención de nadie (ni siquiera de la Corte Suprema).

¡Vaya cualquier abogado a impetrar una excarcelación con una amenaza de pena de medio siglo!

El problema es la forma perversa en que se llega a ese cálculo, o sea, mediante un tipo penal inconstitucional, de raíz persecutoria sindical, agravado en un momento de violencia que pasó hace medio siglo, desdoblando el hecho único que un entendimiento racional impone en el número de hechos que cada juez quiera o invente, convirtiendo un concurso ideal en real, aplicando una escala máxima superior al más grave de todo los delitos, todo para imponer prisiones preventivas inexcarcelables y de ese modo mantener presos a opositores políticos.

Puede sumarse a todo lo dicho la invención de la llamada doctrina de los vínculos 
residuales, que no la registra ni el último folleto del último anaquel de la más remota biblioteca jurídica, el insólito procesamiento por traición a la Nación sin guerra contra la expresa definición constitucional, el impedimento a que un procesado se trate un cáncer, como también el armado de los tribunales por decreto, la persecución a jueces por el contenido de sus sentencias y la amenaza mediante espías a otro, la recusación sin causa en el fuero penal, las instrucciones presidenciales al Consejo de la Magistratura y el manifiesto deseo del ejecutivo de tener jueces propios, máxima expresión de sinceridad nunca antes manifiesta.

En síntesis, dejamos explicado en los términos más simples posibles, el sencillo método para clonar procesos y prisiones preventivas corriente en nuestros días, por supuesto, del lado perverso del derecho. Seguirán consumiendo psicofármacos, porque quienes lo hacen también pasaron por una Facultad de Derecho y nada de lo dicho ignoran.

\section{CONCLUSIONES}

El positivismo jurídico es la metodología propia del constitucionalismo garantista, insiste, en su debate con el principalismo alemán, Luigi Ferrajoli. Suscribimos esta afirmación básica. El positivismo es hoy un refugio seguro paras las garantías penales y procesales, tan vapuleadas. La politización, en consecuencia, no viene de la mano del garantismo constitucional, como a menudo se repite en los medios, sino a la inversa: del no garantismo constitucional. La politización es pues (representada por) el anti garantismo. El juez garantista es el único juez verdaderamente "independiente", artífice y defensor del estricto Derecho (no otra cosa es preservar el "garantismo" constitucional, las garantías procesales, penales, sociales, personales). Es el único juez que está cumpliendo debidamente con su trabajo. Defender las garantías de la constitución. Digan lo que digan los medios, la función del juez es resistir también las presiones mediáticas (que pretenden mellar su independencia), máxime cuando son inconstitucionales, aunque estén masivamente divulgadas $\mathrm{e}$ instaladas como prejuicio o lugar común naturalizado. Los prejuicios suelen forjar visiones inconstitucionales. No es nuevo. Como afirma Adama Dieng, asesor de la ONU sobre la prevención del genocidio, el Holocausto no empezó con las cámaras de gas. Empezó mucho antes, con el discurso del odio. Ese es un discurso repetido a diario, para criminalizar sectores vulnerables y vulnerados, sean disidentes, pobres, indigentes, inmigrantes "ilegales", musulmanes, judíos, gitanos, indígenas que reclaman tierras, activistas o defensores de derechos humanos o medio ambiente, disidentes políticos, opositores. La construcción del enemigo interno es producto de un desvió pocas veces mencionado: la falacia de la seguridad nacional, que en rigor se contrapone a un principio rector de la ONU, hoy absolutamente marginado y en desuso: el principio de la cooperación entre países, el principio de la seguridad colectiva (que también se debiera replicar internamente, no aislando ni criminalizando sectores). La única manera de construir seguridad es construyendo desarrollo y generando inclusión. Preservar las garantías. No alegar que la seguridad se construye recortando garantías o derechos humanos del gararantismo o de la Doctrina Zaffaroni. Es un absurdo que la seguridad se construya discursivamente recortando derechos o estigmatizando garantías. Es un contrasentido práctico y un absurdo teórico y retórico, al que, sin embargo, parecemos estar muy acostumbrados. El anti garantismo, en la medida en que recorta derechos humanos (a los delincuentes, opositores y cualquiera designado como enemigo) es una forma del discurso del odio y como tal censurable. $\mathrm{Ni}$ más ni menos. Es la misma lógica que Teodoro Adorno descubre detrás de los campos y que perdura todavía, con otro nombre: hoy lo llamamos anti garantismo. Hay cárceles que matan (un "escenario atroz para las personas", declaró la Sala II de la Cámara de Casación Argentina, en Junio 201926), mientras ministros repiten que el problema de la inseguridad no es generado por la exclusión, la miseria, o la desigualdad criminal que vive la región; el problema, se dice y se repite, son los derechos, son las garantías... que, habría que acotar, habría que seguir recortando. Nosotros entendemos que es exactamente al revés de lo que plantean algunos ministros: la inseguridad

26 Véase Meyer (2019). "Casación reconoció la superpoblación de la cárcel de Marcos Paz y prohibió nuevos ingresos. La Sala II de la Cámara de Casación hizo lugar a un habeas corpus colectivo y exigió el resguardo de los derechos de los detenidos. Los jueces observaron que en celdas individuales hay más de un detenido y que se eliminó el espacio destinado al gimnasio. Marcos Paz tiene cupo para 1472 personas, pero en este momento hay más de $2800^{\prime}$, reza el informe de la Cámara de Casación argentina. 
es producto de la falta de garantías (de la falta de garantismo social, penal y económico), y de la falta de derechos. No al revés. Es producto de la falta de desarrollo y de la falta de equidad social y de igualdad de derechos. El penalismo refuerza la desigualdad, no la combate: por eso es selectivo. Por eso las cárceles son lo que son. No producen nada bueno. Porque no respetan ninguna garantía. Ningún derecho. Es una hipocresía insostenible en pleno siglo XXI seguir hablando de rehabilitación. Si Jakobs está de moda es porque expresa algo que nadie hubiera querido tener que decir o reconocer: que todo o casi todo el derecho penal funciona de hecho -y las causas armadas son cabal y dramática prueba de ello- como derecho penal del enemigo. Que no hay otro derecho penal más liberal ni más humano (como le objetó Wolfgang Naucke a Zaffaroni en Frankfurt en 2014 en una conferencia en la Universidad Goethe de esa ciudad, coordinada por Klaus Gunter) que esto que vemos con dramática elocuencia y que se resume en la crítica anti democrática e inconstitucional al garantismo de los jueces polémicos. A los que reclaman un derecho penal más humano. Unos jueces capaces de operativizar los derechos sociales. De hacer realidad una promesa jurídica. Una veleidad del garantismo: la equidad.

\section{Un comentario final sobre nuestra tarea posible en criminologia latinoamericana}

Rosa del Olmo (1990) y Lola Anillar de Castro (1981) introdujeron la criminología crítica en América Latina, sin embargo, la crítica que tenemos que hacer hoy nosotros en América Latina es muy diferente de la que valientemente introdujeron desde Venezuela, desde la Universidad Central de Caracas, aquellas autoras. La criminología crítica surge en estados de bienestar que hacían control social, algo que nosotros hoy ya casi no tenemos, hoy lo que existe en la región $\mathrm{y}$ el mundo son totalitarismos financieros que vacían de todo contenido a los llamados estados de bienestar, la cara simpática del capitalismo productivo ha desaparecido (hoy se habla de costo laboral, de presión tributaria, se desintegran y atacan políticas sociales, se estigmatiza al mejor estilo Friedman (1988) toda ayuda o asistencia $\operatorname{social}^{27}$ ), afectando

27 Ese "nuevo" liberalismo económico contrasta con los principios y valores del "viejo" liberalismo politico, que también el margen de acción política de sus clases dirigentes: por eso ya no se habla de gobierno político (contracara del avance de los derechos) sino de gobernanza (administrativa, la emergencia de lo administrativo por sobre lo político es otra de las caras de este proceso de retroceso de la política -recorte de derechos sociales- hecho en favor de las finanzas trasnacionales, del financierismo (FfrenchDavis, 2008)). El control social punitivo (el ajuste se sostiene con control punitivo, el ajuste va de la mano de la represión social, del punitivismo extremo, en esto simbólicamente Chile es un perfecto ejemplo: se modernizó su economía con Pinochet... curioso ejemplo para los neoliberales, que terminan elogiando una dictadura genocida, anti democrática, pero buena en lo económico, mito desmentido por el profesor Ricardo French Davis, siendo que hasta el Banco Mundial reconoció adulterar las estadísticas macroeconómicas de su economía modelo) hoy se realiza de una manera mucho más perversa y cruel que la que pensaron los criminólogos críticos en su momento: hoy la aspiración es que los más excluidos (presos) se maten entre ellos (con periodistas que hablan en los medios masivos inclusive de muertes ecológicas, de presos que se masacran entre ellos como algo positivo, como muertes que le hacen bien al ecosistema, como muertes buenas, positivas). Hoy la ambición es que el mercado se regule solo también en este punto: aislando a los presos, a los pobres, alejándolos, del otro lado de una pared, que no es solo la cárcel, es una nueva pared simbólica. Los pobres quedan lejos, debajo del puente, del otro lado de la frontera, del countrie, del barrio privado. Lejos. Se pueden incluso ahogar en el mar, en el océano, que no lo vemos. No lo queremos saber. No queremos enterarnos. (No sabía $^{28}$ ) Cuando vemos esta realidad social y nos encontramos, en la facultad de derecho, con la importación de teorías como la de Roxin,

compartía ideas que Friedman denuesta, como la idea de derechos humanos inherentes o un Estado capaz de coadyudar en la construcción individual de mayor autonomía: el mercado no genera individuos autónomos, sino cada día más pobres y dependientes. Menos libres. Los reduce a recursos. A cosas. Una cosa no es libre. Un "recurso" humano tampoco. Solo las personas tienen libertad. Y la personalidad es ante todo, cosa que Friedman ignora, un derecho construido artificialmente, por el "viejo liberalismo" politico (moderno), con sus "costosos" derechos sociales, humanos, laborales, base de cualquier "autonomía" moral.

28 Un diario alemán (Der Tagesspiegel) acaba de publicar los 33932 nombres (Die Liste, La Lista, en alemán) de ahogados (cientos de niños) en el mar mediterráneo ante la criminal indiferencia de la Europa civilizada. 
surgen preguntas incómodas. Ciertas teorías en Alemania pueden tener un sentido que en Latinoamérica no tienen. No cabe duda de que Klaus Roxin es un gran dogmático, que Gunter Jakobs es otro gran dogmático, pero teorizan para una realidad diferente. Hay algo que es grave. Sea Roxin con su neokantismo que metodológicamente le hace dejar de lado los datos sociales del poder punitivo, o sea Jakobs, a quien directamente no le interesan, ya que solo le preocupa la función del Estado como proveedor de seguridad jurídica, lo cierto es que la realidad alemana tiene un margen bajo de diferencia entre teorías y prácticas punitivas, margen que en Latinoamérica deviene abismo. Y esta diferencia es sustancial, porque es la causa del idealismo sobre el que ha vuelto la filosofía alemana. Filosofía que, por otro lado, como nos recuerda Adorno, era la filosofía predominante en Alemania cuando cundió el nazismo $^{29}$.

Se termina generando así pedagógicamente (a menos que revisemos nuestros contenidos y programas de enseñanza penal) un programa punitivo que termina dejando afuera los datos de la realidad social. Pero cuidado. Porque los datos de la realidad social en este caso son los datos del ejercicio del poder punitivo. El ejercicio del poder punitivo alemán tiene un ser que se separa del deber ser, pero no en forma disparatada, como en Latinoamérica, donde la importación teórica redunda en lo que Roberto Schwarz llamó una idea fuera de lugar ${ }^{30}$. Lo que queda afuera de la construcción en Alemania no es un disparate. En Alemania no se ejerce la tortura todos los días. En Alemania no hay que juntar muertos de la policía todos los fines de semana. En Alemania no aparecen pozos llenos de cadáveres. En Alemania no tienen el 50 o $60 \%$ de presos en prisión preventiva. En Alemania no tienen sus cárceles convertidas en campos de concentración ${ }^{31}$. El daño que este

29 Como bien sostuvo Friedrich Spee, las brujas no existen, pero el sistema continuamente las inventa. Y las inventa por algo. Porque necesita sostener programas de criminalización punitiva (persecución) basados en estereotipos, que tienen objetivos no siempre claros, pero casi siempre son de naturaleza económica (Zaffaroni, E. R. y Croxatto, G. L., 2017).

30 Schwarz, R. Aparecido primero como "Dépendance nationale, déplacement d'idéologies, littérature" en L'Homme et la Société 26 (Paris, 1972). Luego como "As idéias fora do lugar" en Estudos CEBRAP 3 (San Pablo, ene. 1973) y, bajo el mismo título, como primer capitulo del volumen Ao vencedor as batatas. Forma literária e processo social nos inícios do romance brasileiro (San Pablo, 1977).

31 La Sala II de la Cámara de Casación, que funciona en Buenos Aires, Argentina, acaba de calificar a la cárcel de Marcos Paz como un "escenario atroz para las personas" divorcio de ideas puede producir en Alemania es relativo y los jueces pueden afrontarlo. Pero cuando traemos estas construcciones a América Latina, lo que dejamos fuera del conocimiento de nuestro saber jurídico es lo esencial y más importante. ¿Entonces qué es lo que estamos haciendo importando estas doctrinas, que preparamos para operadores y jueces? Los estamos entrenando, con estas teorías extranjeras, para que ignoren abiertamente esta realidad disparatada de ejercicio de poder punitivo latinoamericano. Esto es mucho más grave, esto no pasó por la cabeza ni de Jakobs ni de Roxin ni ellos tienen la culpa de esto. La culpa de esto la tenemos nosotros. Este es un gran problema. Ellos están pensando en otro contexto de ejercicio del poder punitivo, que tiene sí su selectividad, pero no la selectividad nuestra, que es indignante, racista y letal. No podemos usar teorías para describir una realidad como la nuestra, que dista mucho de la realidad alemana. Parecen verdades evidentes, casi verdades de perogrullo, pero a menudo no lo tenemos en consideración. Y construimos un normativismo formal idealista imposible de compatibilizar con las demandas sociales existentes. Construir un derecho o una criminología que sea herramienta de esas demandas sociales parece más consistente y honesto que importar formalidades vacías de contenido o que fueron y son pensadas para realidades muy diferentes de las latinoamericanas, y que a menudo no están desconectadas de ella, sino conectadas, precisamente, como se conectan el centro y su periferia. Perder de vista esta asimetría teórica es funcional para seguir manteniendo y normalizando jerarquías artificiales: asimetrías prácticas (roles). La desigualdad. No es casual que muchos procesos penales arbitrarios se libren contra líderes populistas, que han cuestionado, precisamente, estas asimetrías económicas y sociales, esta colonización financiera, cultural, económica, y jurídica, intentando elevar el nivel de vida

\footnotetext{
detenidas en ellas. Idéntica conclusión del informe del Sistema Interinstitucional de Control de Cárceles, que analizó el estado de las celdas de la Unidad Penal 29, ubicada en Comorodo Py: tales celdas, amén de su estado de abandono y degradación, hacinamiento, frío, hambre, deberian ser de tránsito, pero son, como en tantos casos, empleadas como celdas de una cárcel común, para lo cual no están preparadas. Esto redunda en una sistemática y atroz violación de derechos procesales y humanos, de forma y de fondo, como solia decirse en derecho procesal. Los presos argentinos tienen casi todos sus derechos básicos violados. En el mismo edificio donde funcionan tribunales de justicia. El contraste no podria ser más simbólico o elocuente. Véase Soriano, F. (2019).
} 
de nuestros pueblos (Zaffaroni, 2017). De los pueblos nuestroamericanos, como bien dice en Argentina Alberto Filippi. El derecho penal debe volver a pensar la colonización, esa herida abierta y sangrante, ese lenguaje que todavía empleamos. Esa mirada sobre recursos sin derechos, que se castigan cuando se resisten al rol que les cabe. A la función que les toca ${ }^{32}$.

\section{FUENTES DE INFORMACIÓN}

\section{Fuentes bibliográficas}

ADORNO, THEODOR W. (1992). Meditación sobre la metafísica. En: Dialéctica negativa (pp. 361-373), trad. J. M. Ripalda. Madrid, España: Taurus.

AGAMBEN, G. (2000). Lo que queda de Auschwitz. El archivo y el testimonio. Trad. A.G. Cuspinera. Barcelona, España: Pretextos.

ANIYAR DE CASTRO, L. (1981). Conocimiento y Orden Social: Criminología como legitimación y criminología de la liberación. Maracaibo, Venezuela: Instituto de Criminología.

BAUMAN, Z. (1998). Modernidad y holocausto. Madrid, España: Sequitur.

BERNSTEIN, E. (1990). Socialismo democrático. Madrid, España: Editorial Tecnos.

32 Pocas voces se alzaron para denunciar la arbitrariedad de la detención en Austria del avión del presidente Evo Morales: porque este presidente es un indio. El avance con causas sobre "terrorismo" sobre indigenas que reclaman tierras (que sin dudas les pertenecen y preservan mejor que las industrias extractivas, que erosionan y destruyen el suelo, el agua, y el aire) es un claro ejemplo. La represión de los reclamos indigenas (en nombre de la "seguridad de las inversiones", en general extranjeras) es un ejemplo de la poca integración pos-colonial de latinoamericana, seguimos operando con una mentalidad aún colonizada, que expolia recursos, acallando reclamos. El Derecho Penal -la Pena que éste legitima y teoriza- suele ser un instrumento de este proceso de expoliación criminal. De destrucción masiva de recursos "humanos", de destrucción de recursos que hacen a la historia y a la identidad de cientos de comunidades originarias, tratadas hoy como "terroristas" o como criminales cuando reclaman por sus derechos más elementales y básicos, la no contaminación de sus ríos. Los conflictos en el sur Argentino (los crimenes de Santiago Maldonado o Rafael Nahuel por fuerzas federales expresan estas tensiones coloniales irresueltas, conflictos, en nuestros Estados poco o nada independientes, que terminan siendo meras burocracias al servicio de la fuga de capitales (Hobsbawm), del empobrecimiento planificado de nuestros paises, burocracias (coptadas) al servicio de la expoliación de nuestros pueblos (Alterini, 2009).
DEL OLMO, R. (1990). Sobre una criminología propia de América Latina. En Rosa del Olmo: Segunda Ruptura Criminológica. Caracas, Venezuela: Universidad Central de Venezuela.

FEDERICI, S. (2018). "La gran caza de brujas en Europa", en: Calibán y la bruja. Mujeres, cuerpo y acumulación originaria, trad. Verónica Hendel y Leopoldo Sebastián Touza. Buenos Aires, Argentina: Tinta limón.

FEDERICI, S. (2018). La gran caza de brujas en Europa, en: Calibán y la bruja. Mujeres, cuerpo y acumulación originaria, trad. Verónica Hendel y Leopoldo Sebastián Touza. $2^{\mathrm{a}}$ reimpresión. Buenos Aires, Argentina: Tinta limón.

FERRAJOLI, L. (2018). Derecho y razón. Teoría del garantismo penal. Madrid, España: Trotta.

FRIEDMAN, M. (1988). Libertad de elegir. Hacia un nuevo liberalismo económico. Madrid, España: Grijalbo.

FULLER, L. (1999). Los exploradores de cavernas. Buenos Aires, Argentina: Ed. Abeledo Perrot.

HABERMAS, J. (1998). Facticidad y validez. Sobre el Derecho y el Estado democrático en Derecho en términos de teoría del discurso. Madrid, España: Ed. Trotta.

KAFKA, F. (1999). La Colonia penitenciaria. Obras completas. Buenos Aires, Argentina: Losada.

NIETZCHE, F. (1998). El nacimiento de la tragedia. Madrid, España: Alianza.

NUSSBAUM, M. (2012). Por qué la democracia necesidad de las humanidades. Buenos Aires, Argentina: Ed. Katz.

SCHMITT, C. (1996). Sobre el parlamentarismo. Madrid, España: Tecnos.

ZAFFARONI, E. R. (2016). Derecho Penal Humano y poder en el siglo XXI. Bogotá, Colombia: Editorial Ibañez.

ZAFFARONI, E. R. (2017). El derecho latinoamericano en la fase superior del colonialismo. Buenos Aires, Argentina: Ed. Madres de Plaza de Mayo. 
ZAFFARONI, E. R. (2018). Doctrina penal nazi. Buenos Aires, Argentina: Ediar.

ZAFFARONI. E. R. y dos Santos, Ilison Días (2019). La nueva crítica criminológica. Criminología en tiempos de totalitarismo financiero. Quito, Ecueador: Ed. El Siglo.

ZAGREBELSKY, G. (2016). El Derecho dúctil Ley, derechos, justicia. Madrid, España: Ed. Trotta.

\section{Fuentes hemerográficas}

ALEN, L. y CROXATTO, G. L. (2018). $\mathrm{La}$ inconstitucionalidad de la ley del arrepentimiento (y la nulidad de los acuerdos celebrados en la causa de las fotocopias). En Revistas de Criminología y Derecho Penal. (11). Pp. 65-82.

ALTERINI, A. (2009). La injusticia de la deuda externa. En Persona. (77).

FERRAJOLI, L. (2011). Constitucionalismo principalista y constitucionalismo garantista. En Revista Doxa. Cuadernos de Filosofia del Derecho. N 34, pp. 15-23.

FFRENCH-DAVIS, R. (2008). Del financierismo a la macroeconomía real. En Ensayos Económicos BCRA, (52), PP. 1-21.

GLENDOM, M. A. (1998). El lenguaje de los derechos. En Revista Estudios Públicos, (70). Tomado de Capítulos 1,2 y 7 ("The Land of Rights", "The Illusion of Absoluteness" $y$ "Refining the Rethoric of Rigths") del libro de Mary Ann Glendon, Rifhts Talk. The Improverishment of Political Discourse (Nuevo York: The Free Press, 1991).
RUSCONI, M. (2018). Arrepentidos y justicia penal. ¿Nuevas formas de combatir la criminalidad organizada o inquisición del nuevo milenio? En Revista Pensar en Derecho, $\mathrm{N}^{\circ} 13$ (5), pp. 9-18.

ZAFFARONI E. R. y Croxatto, G. L. (2017). Friedrich Spee: De la caza de brujas al moderno derecho penal. En Revista Pensar en Derecho, pp. 61-104.

\section{Fuentes electrónicas}

CROXATTO, G. L. (2018). La judicialización de la política. Disponible en: https://www. pagina12.com.ar/128327-la-judicializacionde-la-politica

MEYER, A. (2019). Un escenario atroz para las personas presas. En Diario Página 12. Disponible en: https://www.pagina12. com.ar/203784-un-escenario-atroz-para-laspersonas-presas

PÁGINA 12 (2019). Un panorama judicial sinceramente deplorable. Disponible en: https://www.pagina12.com.ar/206035-unpanorama-judicial-sinceramente-deplorable

SORIANO, F. (2019). Presos amontonados, sucios y con comida podrida: las condiciones inhumanas de las celdas de Comodoro Py, en Portal Infobae. Disponible en: https://www. infobae.com/sociedad/policiales/2019/07/10/ presos-amontonados-sucios-y-con-comidapodrida-las-condiciones-inhumanas-de-lasceldas-de-comodoro-py/ 